\title{
Modifying effects of Soybean and Nigella Sativa against Experimental Hepato-carcinogenesis induced By Nitrosamine Precursor in Rats. (Histopathological and electron microscopically study)
}

\author{
*Hanaa F. Waer, **Abdel Baset EL Asser, ***Hamdy A. Ibrahim, \\ ***:Maher M. Khalifa, **Saad M Elgendy, and**** Khaled I. Magrabi \\ * National center for radiation research and Technology Atomic Energy Authority Cairo Egypt \\ **Cancer Biology Depart. Cancer Institute, Cairo University ***Zoology Depart. Faculty of \\ science Mansora and Cairo University Cairo ****Zoology Depart Faculty of Medical \\ Technology Alfatah University Libya
}

\begin{abstract}
Cancer has become an important topic in medicine since it is a major cause of death in the developing countries and it is now only secondary to that of myocardial infraction. Nitrosamines precursors are known to be carcinogenic to humans, in various organs at relatively low levels of exposure. It induces benign and malignant tumors especially liver tumors following its administration by various routes, including ingestion and inhalation. Humans may be exposed to Nitrosamines through the ingestion of food that contains it, such as cured meat products, and smoked fish. Other exposures to Nitrosamines may be from drinking contaminated water and from breathing cigarette smoke and contaminated ambient air. Individual are most likely to be exposed to Nitrosamines in occupational settings such as in the rubber, tannery, fish processing, dyes, and surfactant industries. The prevalence of liver tumors throughout the world makes in imperative to seek chemo preventive agents.

Vegetables, natural products of plant origin and numerous non-nutritive dietary constituents have been shown to play a salutary role in cancer chemoprevention. The present study aims to evaluate the chemo preventive efficacy of soy bean and Nigella sativa on hepatocarcinogenesis induced by dibuty1 nitrosamine (DEN).

It could be observed that both soy bean and Nigella sativa have a good effect of amelioration against liver hepatoma induced by nitrosamine. Soy bean more or less showed more prerogative effect than Nigella 9 and 12 months after administration.
\end{abstract}

\section{Introduction}

Nitrosamine is volatile, clear yellow oil that is soluble in water, alcohol, ether, other organic solvents, and lipids. The compound is sensitive to light, especially ultraviolet light, and undergoes relatively rapid photolytic degradation. When heated to decomposition, $\mathrm{N}$-nitroso-dibutylamine emits toxic fumes of nitrogen oxides (NO).$\mathrm{N}$ - nitroso-dibutylamine is used primarily as a research chemical. It is used as a gasoline and lubricant additive, antioxidant, stabilizer, fiber industry solvent, copolymer softener and starting material for synthesis of 1, 1- diethyl hydrazine. It is also used to increase constants in condensers.

Since the discovery of the carcinogenic property of nitrosamine many other nitrosamines have been found to induce malignant tumors in various species of laboratory animals (Magee \& Barnes, 1967). There is growing concern with regard to certain nitrosamines as etiological agents for cancer in the human environment (Lijinsky \& Epstein, 1970). It is generally accepted that the use of nitrite as a food preservative may be associated with the formation of nitrosamines in foods as well as in the animal organism. The nitrosamines vary in their carcinogenic potential. They can induce malignant tumors at very low levels, such as $2 \mathrm{ppm}(0.0002 \%)$ in the diet of rats (Terracini et al., 1967), equivalent to daily doses of $0.1 \mathrm{mg} / \mathrm{kg}$ bw. A single oral dose of $30 \mathrm{mg} / \mathrm{kg}$ BW of nitrosamine proved to be carcinogenic in the rat (Druckrey et al., 1969). Tumors of the trachea developed in the offspring of hamsters treated either during pregnancy or 
lactation with nitrosamine (Moss, and Henderson, (1996)

It has been affirmed that nitrosamine is carcinogenic. Nitrosamine contents were observed in water from high incidence areas of liver cancer in the 1970s and 1980s in China, but the test method used was not very sensitive for semi-quantity (Liu et al., 1996)

Food-derived products are highly interesting for developing as chemo preventive agents that may find widespread, long-term use in populations at normal risk, because of their safety and the fact that they are not perceived as "medicine".

Numerous diet-derived agents are included among the combinations that are being evaluated clinically as chemo preventive agents for major cancer targets including liver cancer. Examples include green and black tea polyphenols, soy isoflavones, black seed named as Nigella sativa and curcumin. Sakata et al. (2004), and Singh et al. (2004), found that dietary supplementation of the citrus antioxidant auraptene inhibits $\mathrm{N}, \mathrm{N}$-diethyl nitrosamineinduced rat hepato carcinogenesis.

The antioxidant and anti-carcinogenic activities of soybean isoflavones extracts were investigated by Lee et al. (1998), (2002). They found that soy bean isoflavones may have anti-carcinogenic effect the protective role of soy bean feeding against the cytogenetic and histopathological effects of nitrosamine precursor's sodium nitrate and dibutylamine was evaluated by Tohamy et al., (1996), they noticed a marked reduction in dysphasic features in the liver cells. The cytogenetic and histopathologic results of their study strongly support the protective role of soy bean against the genotoxic and carcinogenic action of nitrosamine formed in vivo from its precursors.

On the other hand, Taniguchi et al. (2000), declared that sufficient amounts of methionine and cystine in Soy bean diet are important to protect the liver from oxidative damage after NDMA administration, and GSH plays a primary role in the cellular protective function. Iddamaldeniya et al. (2003), indicate that the decoction comprised of N. sativa, S. glabra and $\mathrm{H}$. indices has a potential effect to protect rat liver against di-butylnitrosamine [DEN] induced hepatocarcinogenisis.

Islam et al. (2004), come to the fact that Nigella Sativa could be considered as a potential immunosuppressive cytotoxic agent, Salim and Fukushima (2003), stated that the volatile oil of $N$. sativa has the ability to inhibit colon carcinogenesis of rats in the post initiation stage, with no evident adverse side effects, and that the inhibition may be associated, in part, with suppression of cell proliferation in the colonic mucosa.

Benghuzzi et al. (2003), discuss the role of black seed in the proliferation and bio-chemical marker levels of Hep-2cells; they come to the fact that the use of black seed Nigella sativa reversed the traumatic condition.

\section{Materials and Methods Animals:}

In the present study, young male Swiss albino rats weighting about 30-40 g were used. Animals were kept under normal laboratory conditions for 7 days before starting the experiment. They were fed on standard normal diet or standard commercial diet (Egyptian Company of Oils and Soaps) containing 24\% proteins, $5.5 \%$ fibers, $5.5 \%$ ash. Animals were provided with tap water ad-libitum.

\section{Treatments:}

Rats were divided into 7 main groups, each consisting of 20 rats. Groups were treated as follows:

Group 1: control untreated group.

Group 2: Dibutylamine and sodium nitrate (the carcinogenic, complex)-treated group: animals fed with normal diet and drinking tap water ad-libitum containing 1000 ppm dibutylamine (DBA) and $2000 \mathrm{ppm}$ nitrate as sodium nitrate (Sigma) for 3 months. The amine and nitrate were mixed together with the drinking water using a magnetic stirrer for a period of $15 \mathrm{~min}$. for 3 months.

Group 3: Soy bean. Animals were fed the control diet well mixed with $20 \%$ of autoclaved soy bean $\left(105^{\circ} \mathrm{C}, 15 \mathrm{~min}\right)$. (Egyptian Poultry Co.) The soy bean used contained : $1-2 \%$ fats, $44.4 \%$ protein, $10-$ 
$11 \%$ moisture, $8.8 \%$ ash, $3.2 \%$ fibers and trypsin inhibitor $10.36 \mathrm{unit} / \mathrm{mg}$ and drinking tap water ad-libitum.

Group 4: Dibutylamine, sodium nitrate and 20\% soy bean-treated group: Animals fed with control diet containing $20 \%$ autoclaved soy bean performed at $150^{\circ} \mathrm{C}$, $15 \mathrm{~min}$. and drinking tap water containing carcinogenic complex as described for Group 2 for another 3 months till the end of experiment (12 months).

Group 5: Dibutylamine, sodium nitrate, 205 soy bean and $10 \%$ Nigella sativatreated groups. Animals fed with control diet containing $20 \%$ autoclaved soy bean and $10 \%$ Nigella sativa powder seed and drinking tap water with carcinogenic complex as described for Group 2, only for another 3 months (12 months).

Group 6: Nigella sativa. Animals were fed the control diet well mixed $10 \%$ of Nigella sativa (Egyptian Poultry Co.) seeds powder and drinking water ad-libitum for 12 months.

Group 7: Dibutylamine, sodium nitrate, and $10 \%$ Nigella sativa-treated group: Animals fed with control diet containing $10 \%$ Nigella sativa powder seed and drinking tap water containing carcinogenic complex as described for Group 2, for another 3 months only till the end of experiment (12 months).

The animal's body weight was recorded every week. Five rats from each group were sacrificed regularly every 3 months and the liver, spleen of each group were removed from sacrificed animals weighted. Pieces of liver were frozen in liquid nitrogen then stored in deep freezer at $-80^{\circ} \mathrm{C}$.

\section{Histopathologic preparations:}

Pieces of liver tissue were fixed in $10 \%$ formalin for 24 hours. Paraffin sections were stained with haematoxylin and eosin for histological examination according to Carleton, (1980).

\section{E.M. preparations:}

Small pieces of liver from each group were fixed in $2.5 \%$ glutaraldehyde and post fixed in $1 \% \quad \mathrm{O}_{5} \mathrm{O}_{4}$. The fixed tissues were dehydrated in ascending grades of acetone, followed by infiltration and embedding in Spurr's low viscosity medium. Blocks were then cut into sections $(800-900 \%)$ with Diatom diamond knife on an MT 600-XL RMC Ultra-tome.

Sections were collected on 200-mesh nickel grids and stained in 5\% uranyl acetate in glass distilled water for 10 minutes. Sections were then stained in lead citrate for 6 minutes (Venable \& Coggeshall, 1965) and were examined with a Joel JTM-1200 EX II electron microscope.

\section{Results}

\section{Body weight Variation:}

Table 1Showes the mean body weights of the different animal groups during the periods of the study. The carcinogen groups had the lowest rate of increasing weight in all groups; the protectors had a slight but insignificant improving effect oh $n$ the body weight. In all groups no significant change in body weight could be detected (fig A).

\section{Histopathological studies}

Fig. (1) Illustrated a photomicrograph of a section of rat liver from a control group showing normal pattern of hepatic lobule with normal blood sinusoids. 3 months after treatment with $\mathrm{DBA}+\mathrm{NaNO}_{3}$ showed slight hemorrhage accompanied with necrotic cells Fig. (2). 6 months after treatment showed that the cells are greatly affected with pycknotic nuclei. The portal tract is entirely normal with inflammatory changes and infiltration, Fig. (3). On the other hand, 9 months after treatment showed preservation of hepatic lobular pattern

Signs of cell death illustrated in densely stained pycknotic nuclei and hyalinization and lysis of the cytoplasm. .Some hepatocytes appeared highly vacuolated with increased sinusoidal spaces and small hemorrhagic areas Fig. (4).

Mean while 12 months after treatment showed complete destruction of the portal tract which appeared surrounded by inflammatory cells which are predominantly lymphocytes and plasma cells. The blood sinusoids are large and ill-defined Fig. (5).

Soy bean protected group:

Sections from a rat given DBA + $\mathrm{NaNO}_{3}$ and treated with soybean for 3 
months showed no signs of recovery. Areas of necrosis and disorganized portal tract still observed. (Protective effect is not remarkable) Figs. (6a, b), while sections from rats given $\mathrm{DBA}+\mathrm{NaNO}_{3}$, and treated with soybean for 6 months showed slight recovery and mild regression of cell death pattern. Vacuolated hepatocytes with Karyolytic nuclei and dilated ruptured blood sinusoids were seen in Fig. (7), Debris of many hepatocytes could also be observed.

On the other hand, 9 months after soybean feeding showed increased number of activated nuclei, fatty changes and normal blood sinusoids Fig. (8), while after 12 months. A remarkable ameliorating effect, recovery of the cells could easily recognized and most of the cells are in mitotic division. The cytoplasm is well organized with well defined activated nuclei. Small hemorrhagic areas are still observed Fig. (9)

Nigella protected group:

3 months after treatment with DBA + $\mathrm{NaNO}_{3}$ and Nigella sativa showed no sings of recovery, hemorrhage, area of necrosis pyknotic nuclei and irregular lobular pattern (congested hepatic portal vein) were clear Fig. (10).

On the other hand after 6 months, the cells begin to retain their normality (Fig11).Infiltration and area of inflammation are still observed.

9 months after Nigella protection. Showed that many cells appeared normal while vacuolation, and dilatation of the blood sinusoids were still noticed, Fig. (12). Mean while animals treated for 12 months with Nigella sativa showed remarkable recovery, many cells appeared normal , some of them were in mitotic division as a sign of regeneration, with normal cytoplasm and well organized cell membranes, Others appeared vacuolated Fig. (13)

\section{Soy bean + Nigella protection:}

Rat given DBA $+\mathrm{NaNO}_{3}$ for 3 months and treated with mixed Nigella sativa and soybean showed a remarkable sign of recovery ,normal designed cell with homogenous cytoplasm and activated nucleus(Fig. 14) . Activation of kupffer cells, congestion of blood sinusoids and hemorrhage are still observed 6, 9, 12 months after protection with Soy bean +Nigella showed that mixing Nigella sativa with soybean help very much the liver cells to retain their normality much faster than single dose of each of them .A remarkable regeneration restricted in mitotic figures and activation of the nucleus was observed. The blood vessels and the bile ducts became normal with normal cell linings, binucleated cells as a regression of the effect of nitrosodiethylamine amine. Figs. $(15,16,17)$

\section{Electron microscopic studies}

Mitochondria have double membranes and short cristea. Smooth and rough endoplasmic reticulum appeared well organized, Fig (18).

Fig. (19 - 20) showed, an electron micrograph of a cell from rat liver fed with soybean and Nigella sativa respectively showed normal cytoplasm and nucleus. The mitochondria are healthy but more electron dense than normal. While cristea are not defied slightly increased in lipid droplets was observed in Fig (20).

Electron micrograph of a rat liver fed with soybean + Nigella sativa, reviled normal and well organized cytoplasm \& nucleus Fig. (21).

Rats treated with $\mathrm{DBA}+\mathrm{NaNO}_{3}$ for 3 Months, Showed irregular nucleus with hyper chromatin, increase in glycogen rosette form, area of necrosis and polymorphic electron dense mitochondria. Fig. (22). While those treated with $\mathrm{DBA}+\mathrm{NaNO}_{3}$ for 6 months. showed dark and light cells. The dark cell is completely degenerated while the light is normal (precarcinogenic stage) Fig. (23).

9 months after giving $\mathrm{DBA}+\mathrm{NaNO}_{3}$ showed severe increase in glycogen and lipid granules. Free ribosomes are found in excess amount in the cytoplasm (a sign of cancer stage), Fig (24).

After 12 Months hyaline cytoplasm with greatly affected destructive organoid were observed, Fig. (25).

\section{Soy bean protected group:}

Electron micrograph of a cell from a rat liver given $\mathrm{DBA}+\mathrm{NaNO}_{3}$ and fed with soy bean for 3 months showing no signs of recovery. The cell still weak with typical 
cancer features. The nucleus looks irregular with dense chromatin. The endoplasmic reticulum is proliferated and mega chromatin appeared and lipid droplets are common. Fig (26).

On the other hand examined sections from rats given $\mathrm{DBA}+\mathrm{NaNO}_{3}$ and fed with soy bean for 6 months showed hypertrophy of the endoplasmic reticulum free ribosomes, disturbed mitochondria with absence of their cristea, increased amount of glycogen and fat droplets. The nuclear membrane still irregular with condensed chromatin Fig. (27). While 9 Months after feeding with soy bean declared that soybean helps very much to regain the normality of the cell structure, normal nucleus with normal cytoplasmic inclusions. The mitochondria still more electrons dense with healthy feature, Fig (28).

Examined sections from rats given $\mathrm{DBA}+\mathrm{NaNO}_{3}$ and fed with soy bean for 12 months showing normal structure of the cell with excess amount of glycogen particle. Fig (29).

\section{Nigella sativa protector group:}

Rats given $\mathrm{DBA}+\mathrm{NaNO}_{3}$ and treated with Nigella sativa for 3 months showed mild effect of recovery the nucleus is normal and activated, the cytoplasm is vacuolated with increased amount of lipid and fat droplets . A lot of free ribosomes, $1^{\text {ry }}$ and $2^{\text {ry }}$ lysosomes and glycogen particles were detected, Fig. (30).

Mean while those given DBA+ $\mathrm{NaNO}_{3}$ and treated with Nigella sativa for 6 months. Showed signs of recovery the nucleus is normal and endoplasmic reticulum is well defined, the mitochondria are still week and in some cases they were ruptured Fig (31).

Rats given $\mathrm{DBA}+\mathrm{NaNO} 3$ and fed with Nigella sativa for 9 months showing hepatic cells with normal structure, the nucleus is well organized and the mitochondria are polymorphic dense and small in size. Fat droplets were seen. Fig. (32).

12 months after feeding with Nigella showed that the cell retained its normal appearance architecture Fig. (33).

Nigella sativa + Soy bean protector group:

Rats given $\mathrm{DBA}+\mathrm{NaNO} 3$ and fed with soybean \& Nigella sativa for 3 months showing a marked signs of recovery the nucleus is well defined with double membrane. Pores and normal chromatin. The cytoplasm is well organized with rough ER and healthy nucleus Fig. (34). On the other hand those fed with soybean and Nigella sativa for 6,9 and 12 months showing normal structure of cell organelles. Figs $(35,36,37)$.

\section{List of figures:}

Fig. (1): A photomicrograph of a section of liver rat from a control group showing normal pattern of hepatic lobule with normal blood sinusoids

(Hx \& E). (X 200)

Fig. (2): A photomicrograph of a section from a rat given $\mathrm{DBA}+\mathrm{NaNO}_{3}$ for 3 months. Note hemorrhage accompa-nied with necrotic cells (Hx \& E). (X 200)

Fig. (3): A photomicrograph of a section from a rat given $\mathrm{DBA}+\mathrm{NaNO}_{3}$ for 6 months showing that the cells are greatly affected with pycknotic nuclei, congested with inflammatory changes and cellular infiltration $\quad(\mathrm{Hx} \& \mathrm{E})$.

Fig. (4): A photomicrograph of a section from a rat given $\mathrm{DBA}+\mathrm{NaNO}_{3}$ for 9 months showing preservation of hepatic lobular pattern signs of cellular death illustrated in densely stained pycknotic nuclei and hyalinization with lyses degenerated vacuolated cytoplasm Small hemorrhagic areas. (Hx \& E) (X 200).

Fig. (5): A photomicrograph of a section from a rat given $\mathrm{DBA}+\mathrm{NaNO}_{3}$ for 12 months showing complete destruction of the portal tract which surrounded by inflammatory cells which is predominantly lymphocytes and plasma cells. The blood vessel is large and illdefined.

(Hx \& E). (X 200)

Fig. (6 a, b): A photomicrograph of a section from a rat given $\mathrm{DBA}+\mathrm{NaNO}_{3}$ and treated with soy bean for 3 months showed no signs of recovery with area of necrosis and disorganized portal tract. (Protective effect is not remarkable).

(Hx \& E). (X 200)

Fig. (7): A photomicrograph of a section from a rat given $\mathrm{DBA}+\mathrm{NaNO}_{3}$ treated with soybean for 6 months showing mild 
recovery, highly dilated sinusoidal spaces and mild regression of cell death pattern and many karyolitic nuclei

(Hx \& E). (X 200)

Fig. (8): A photomicrograph of a section from a rat given DBA $+\mathrm{NaNO}_{3}$ treated with S.B for 9 months showing increased number of activated nucleus, fatty changes and normal blood sinusoids and a lot of small hemorrhage patches

(Hx \& E). (X 200)

Fig. (9): A photomicrograph of a section from a rat liver given $\mathrm{DBA}+\mathrm{NaNO}_{3}$ and treated with S.B. for 12 months. Showed that S.B. remarkable recovery of the cells. Some cells appeared in mitotic state. They cytoplasm is well organized with well defined activated nuclei (Hx \& E). (X 200) a lot of small heamorrhagic patches.

Fig. (10): A photomicrograph of a section from a rat given DBA + NaNO3 for 3 months and treated with Nigella sativa showing highly congested hepatic portal vein, dilated sinusoidal spaces with cellular infiltration. (Hx \& E). (X 200)

Fig. (11): A photomicrograph of a section from a rat given $\mathrm{DBA}+\mathrm{NaNO}_{3}$ for 6 months and treated with Nigella sativa showed signs of recovery. The cells begin to retain its normality cellular infiltration is still observed.

(Hx \& E). (X 200).

Fig (12): A photomicrograph of a section from a rat given $\mathrm{DBA}+\mathrm{NaNO}_{3}$ for 9 months and treated with N.S. showing dilatation of the blood sinusoids, many vacuolated hepatocytes appeared normal. (Hx\& E). (X 400).

Fig. (13): A photomicrograph of section from a rat given $\mathrm{DBA}+\mathrm{NaNO}_{3}$ for 12 months and treated with Nigella sativa showing many cells in mitotic division as a sign of regeneration binucleated cells, normal cytoplasm and well organized cell membranes. i.e. Remarkable recovery as an effect of N.S. infective (Hx \& E). (X 1000).

Fig. (14): A photomicrograph of a section from a rat given $\mathrm{DBA}+\mathrm{NaNO}_{3}$ for months and treated with mixed Nigella sativa and soy bean. Showed a remarkable sign of recovery normal designed cell with homogenous cytoplasm and activated nucleus. Activation of kupffer cells dilatation of the blood sinusoids and hemorrhage is still observed.

(Hx \& E). (X 400)

Figs. $(15,16,17)$ : photomicrographs of sections from rat liver given DBA + NaNO3 for 6, 9, 12 months showing that compound mixing of Nigella sativa and soy bean help very much the liver cells to retain their normality a remarkable regeneration restricted in mitotic figures and activation of the nucleus. The blood sinusoids and the bile duct become normal with normal cell linings, binucleated cells as a regression of the effect of nitrosodi-ethylamine. Finally it can be declared that soy bean in combination with Nigella sativa give a good protective effect of the line cells 6 , 9 and 12 months after treatment

(HX\&E) (X 400)

Fig. (18): An electron micrograph of a cell from control normal rat liver, showing normal pattern. The nucleus is well defined with double membranes and chromatin inside. The mitochondria have double membrane and short cristea, smooth and rough endoplasmic recticulum is well organized.

(X 10.000).

Fig. (19): An electron micrograph of a cell from rat liver fed with soy bean. Note: normal cytoplasm and nucleus. The mitochondria are electron dense with not well defined cristea. (X 10.000).

Fig. (20): An electron micrograph of rat liver all fed with Nigella sativa showing normal structure companied with but slightly increased lipid droplets was observed.

(X 6.000)

Fig. (21): An electron micrograph of a rat liver cell fed with soybean and Nigella sativa. Note: Normal and well organized cytoplasm \& nucleus.

$$
\mathrm{X}(10,000)
$$

Fig. (22): An electron micrograph of a rat liver cell DBA $+\mathrm{NaNO}_{3}$ for 3 months. Note: irregular nucleus with hyper chromatin, increased glycogen rosette forms area of necrosis and polymo-rphic electron dense mitochondria.

(X 6000) 
Fig (23): An electron micrograph of a rat liver cell given DBA + NaNO3 for 6 months. Note: dark and light cells.

(Precarcinogenate stage) (X 4000)

Fig. (24): An electron micrograph of a cell from rat liver given $\mathrm{DBA}+\mathrm{NaNO}_{3}$ for 9 months showing severe increase in glycogen and lipid granules. Free ribosomes are found in excess amount in the cytoplasm in excess amount in the cytoplasm

(Typical cancer stage). (X 4000)

Fig. (25): An electron micrograph of a rat liver cell given DBA + NaNO3 for 12 months showing hyaline cytoplasm with greatly affected organoids. (X 8000).

Fig. (26): An electron micrograph of a cell from a rat liver given $\mathrm{DBA}+\mathrm{NaNO}_{3}$ and fed with soy bean for 3 months showing no signs of recovery. The cell still weak with typical cancer feature. The nucleus looks irregular with dense chromatin. The endoplasmic reticulum is proliferated and mega chromatin appeared, lipid droplets are common. (6000x)

Fig. (27): An electron micrograph of cell from rat liver given $\mathrm{DBA}+\mathrm{NaNO}_{3}$ and fed with soy bean for 6 months showing hypertrophy of the endop-lasmic reticulum. Increased amount of free ribosomes, glycogen and fat droplet. The nucleus still irregular with condensed chromatin.

(X 6000)

Fig. (28): An electron micrograph of a cell from a rat liver given $\mathrm{DBA}+\mathrm{NaNO}_{3}$ and fed with soybean for 9 months showing that soy bean helps very much to regain the normality of the cell structure, normal nucleus with normal cytoplasmic inclusions. The mitochondria still appeared more electrons dense with healthy features. (X 10.000).

Fig. (29) : An electron micrograph of a cell from rat liver given $\mathrm{DBA}+\mathrm{NaNO}_{3}$ and fed with soybean for 12 months showing normal structure of the cell with excess amount of glycogen particles.

(X 10.000)

Fig. (30) : An electron micrograph of a part of a cell from rat liver given DBA $+\mathrm{NaNO}_{3}$ and fed with Nigella sativa for 3 moths showing mild signs of recovery, the nucleus is normal and activated, the cytoplasm is vacuolated with increased amount of lipid and fat droplets . Free ribosomes and glycogen particles are found in excess within the cytoplasm. $1^{\mathrm{ry}}$ and $2^{\mathrm{ry}}$ lysosomes are also seen. (X 4000)

Fig. (31): An electron micrograph of a part of a cell from rat liver given DBA + $\mathrm{NaNO}_{3}$ for 6months and fed with Nigella sativa. Showing signs of recovery, normal, nucleus and endoplasmic reticulum, the mitochondria are still week; some of them were distinctive and ruptured. (X 1000)

Fig. (32): An electron micrograph of a part of a cell from rat liver given DBA + $\mathrm{NaNO}_{3}$ for 9months showing hepatocytes has the normal structure. The nucleus is well organized and the mitochondria are polymorphic dense and small in size Fat droplets are seen.

Fig. (33): An electron micrograph of cell from rat liver given $\mathrm{DBA}+\mathrm{NaNO}_{3}$ and fed with Nigella sativa for 12 months showing that the cell retained its normal appearance architecture. (X10000)

Fig. (34) : An electron micrograph of a cell from rat liver given DBA $+\mathrm{NaNO}_{3}$ and fed with soybean + Nigella sativa for 3 months showing marked signs of recovery the nucleus is will defined with double membrane pores and normal chromatin. The cytoplasm is well organized with rough ER and healthy nucleus.

(X 10.000)

Fig. (35) : An electron micrograph of a cell from rat liver given $\mathrm{DBA}+\mathrm{NaNO}_{3}$ and fed with soybean + Nigella sativa for 6 months showing normal structure.

(X 8000)

Fig. (36) : An electron micrograph of a cell from rat liver given $\mathrm{DBA}+\mathrm{NaNO}_{3}$ and fed with soybean + Nigella sativa for 9 months showing normal healthy cell.

(X 4000)

Fig. (37) : An electron micrograph of a cell from rat liver given $\mathrm{DBA}+\mathrm{NaNO}_{3}$ and fed with soybean + Nigella sativa for 12 months showing normal structure of cell organelles.

(X 10000) 
Table I:-

Change in body weight in the different animal groups

\begin{tabular}{|c|c|c|c|c|c|c|c|c|c|c|c|c|}
\hline \multirow{2}{*}{ Groups } & \multicolumn{12}{|c|}{ Experimental period ( months) } \\
\hline & 1 & 2 & 3 & 4 & 5 & 6 & 7 & 8 & 9 & 10 & 11 & 12 \\
\hline Control & $\begin{array}{c}27 \pm \\
5\end{array}$ & $\begin{array}{c}120 \pm \\
18\end{array}$ & $\begin{array}{c}146 \pm \\
11\end{array}$ & $\begin{array}{c}187 \pm \\
15\end{array}$ & $\begin{array}{c}205 \pm \\
17\end{array}$ & $\begin{array}{c}215 \pm \\
20\end{array}$ & $\begin{array}{c}221 \pm \\
20\end{array}$ & $\begin{array}{r}235 \pm \\
21\end{array}$ & $\begin{array}{c}250 \pm \\
25\end{array}$ & $\begin{array}{c}269 \pm \\
24\end{array}$ & $\begin{array}{c}270 \pm \\
27\end{array}$ & $\begin{array}{r}278 \pm \\
31\end{array}$ \\
\hline Carcinogen & $\begin{array}{c}22 \pm \\
6\end{array}$ & $\begin{array}{c}96 \pm \\
14\end{array}$ & $\begin{array}{c}128 \pm \\
10\end{array}$ & $\begin{array}{c}163 \pm \\
14\end{array}$ & $\begin{array}{l}175 \pm \\
15\end{array}$ & $\begin{array}{c}186 \pm \\
15\end{array}$ & $\begin{array}{c}195 \pm \\
18\end{array}$ & $\begin{array}{c}212 \pm \\
20\end{array}$ & $\begin{array}{c}225 \pm \\
22\end{array}$ & $\begin{array}{c}238 \pm \\
26\end{array}$ & $\begin{array}{c}240 \pm \\
27\end{array}$ & $\begin{array}{c}1245 \\
\pm \\
2815\end{array}$ \\
\hline Carcinogen + SB & $\begin{array}{c}26 \pm \\
4\end{array}$ & $\begin{array}{c}100 \pm \\
13\end{array}$ & $\begin{array}{c}132 \pm \\
14\end{array}$ & $\begin{array}{c}155 \pm \\
12\end{array}$ & $\begin{array}{c}185 \pm \\
14\end{array}$ & $\begin{array}{c}198 \pm \\
17\end{array}$ & $\begin{array}{r}214 \pm \\
21\end{array}$ & $\begin{array}{r}225 \pm \\
22\end{array}$ & $\begin{array}{c}235 \pm \\
14\end{array}$ & $\begin{array}{r}243 \pm \\
27\end{array}$ & $\begin{array}{c}254 \pm \\
26\end{array}$ & $257 \pm$ \\
\hline Carcinogen + NS & $\begin{array}{c}23 \pm \\
5\end{array}$ & $\begin{array}{c}95 \pm \\
9\end{array}$ & $\begin{array}{r}130 \pm \\
12\end{array}$ & $\begin{array}{c}152 \pm \\
15\end{array}$ & $\begin{array}{c}175 \pm \\
12\end{array}$ & $\begin{array}{c}205 \pm \\
18\end{array}$ & $\begin{array}{r}211 \pm \\
24\end{array}$ & $\begin{array}{r}228 \pm \\
17\end{array}$ & $\begin{array}{c}246 \pm \\
15\end{array}$ & $\begin{array}{c}256 \pm \\
23\end{array}$ & $\begin{array}{c}262 \pm \\
18\end{array}$ & $\begin{array}{r}263 \pm \\
27\end{array}$ \\
\hline $\begin{array}{l}\text { Carcinogen }+ \text { SB } \\
+ \text { NS }\end{array}$ & $21 \pm 5$ & $\begin{array}{c}105 \pm \\
10\end{array}$ & $\begin{array}{c}124 \pm \\
10\end{array}$ & $\begin{array}{c}154 \pm \\
13\end{array}$ & $\begin{array}{l}189 \\
\pm 13\end{array}$ & $\begin{array}{l}215 \\
\pm 15\end{array}$ & $\begin{array}{l}225 \\
\pm 18\end{array}$ & $\begin{array}{l}235 \\
\pm 18\end{array}$ & $\begin{array}{l}225 \\
\pm 17\end{array}$ & $\begin{array}{l}261 \\
\pm 24\end{array}$ & $\begin{array}{l}263 \\
\pm 19\end{array}$ & $\begin{array}{l}274 \\
\pm 24\end{array}$ \\
\hline SB & $\begin{array}{c}21.5 \\
\pm 6\end{array}$ & $\begin{array}{c}125 \pm \\
8\end{array}$ & $\begin{array}{c}147 \pm \\
11\end{array}$ & $\begin{array}{c}191 \pm \\
12\end{array}$ & $\begin{array}{c}210 \pm \\
8\end{array}$ & $\begin{array}{r}225 \pm \\
17\end{array}$ & $\begin{array}{r}230 \pm \\
17\end{array}$ & $\begin{array}{r}245 \pm \\
19\end{array}$ & $\begin{array}{c}255 \pm \\
18\end{array}$ & $\begin{array}{c}275 \pm \\
21\end{array}$ & $\begin{array}{c}286 \pm \\
24\end{array}$ & $\begin{array}{r}295 \pm \\
24\end{array}$ \\
\hline NS & $23 \pm$ & $\begin{array}{c}124 \pm \\
10\end{array}$ & $\begin{array}{c}135 \pm \\
12\end{array}$ & $\begin{array}{c}185 \pm \\
13\end{array}$ & $\begin{array}{c}215 \pm \\
14\end{array}$ & $\begin{array}{c}230 \pm \\
19\end{array}$ & $\begin{array}{c}225 \pm \\
18\end{array}$ & $\begin{array}{r}238 \pm \\
20\end{array}$ & $\begin{array}{c}259 \pm \\
19\end{array}$ & $\begin{array}{c}275 \pm \\
18\end{array}$ & $\begin{array}{c}282 \pm \\
19\end{array}$ & $\begin{array}{r}293 \pm \\
21\end{array}$ \\
\hline
\end{tabular}

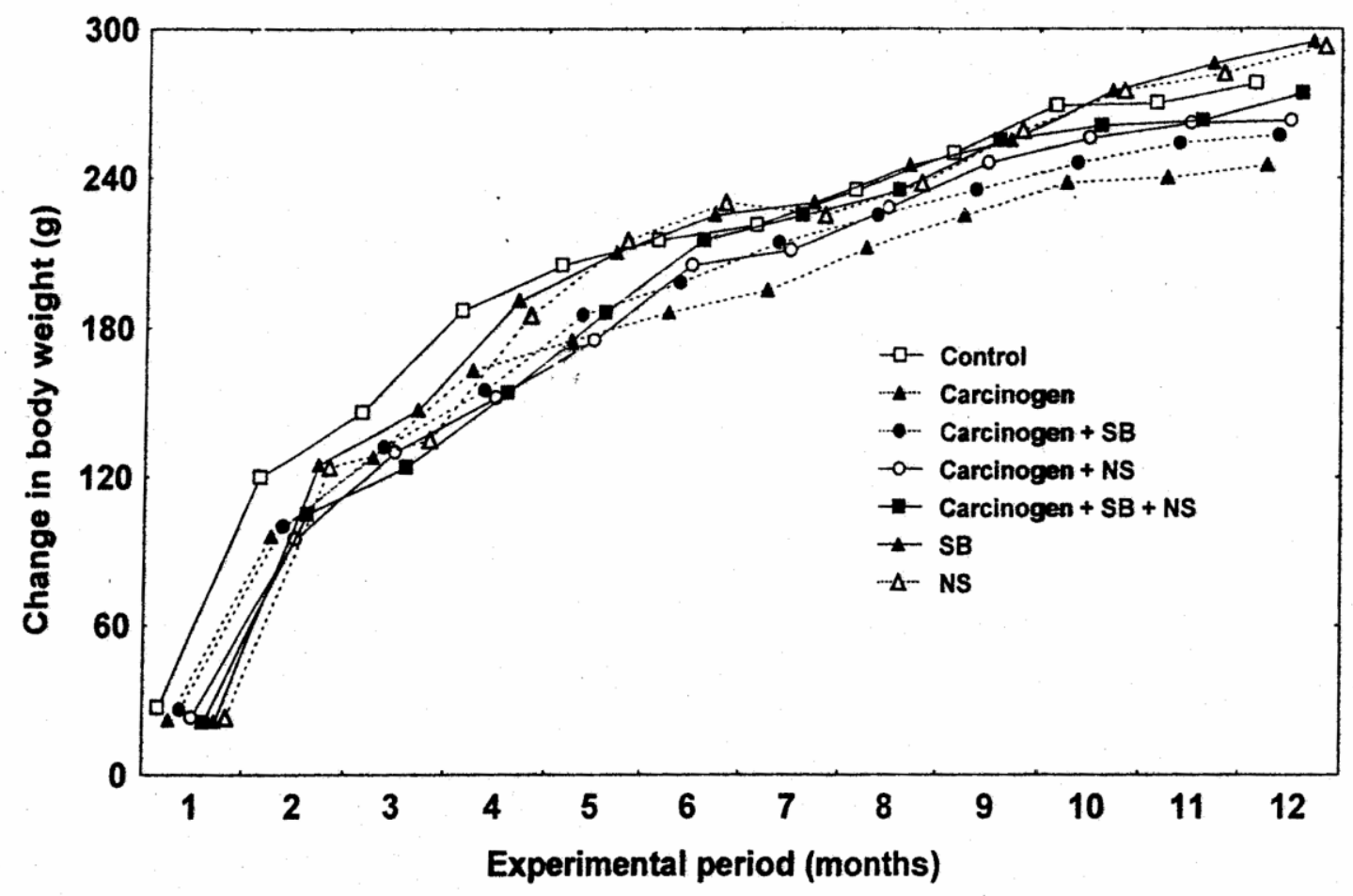

Fig A:-

No Significant could be detected in the body weight among the different groups. 
Modifying effects of Soybean and Nigella............
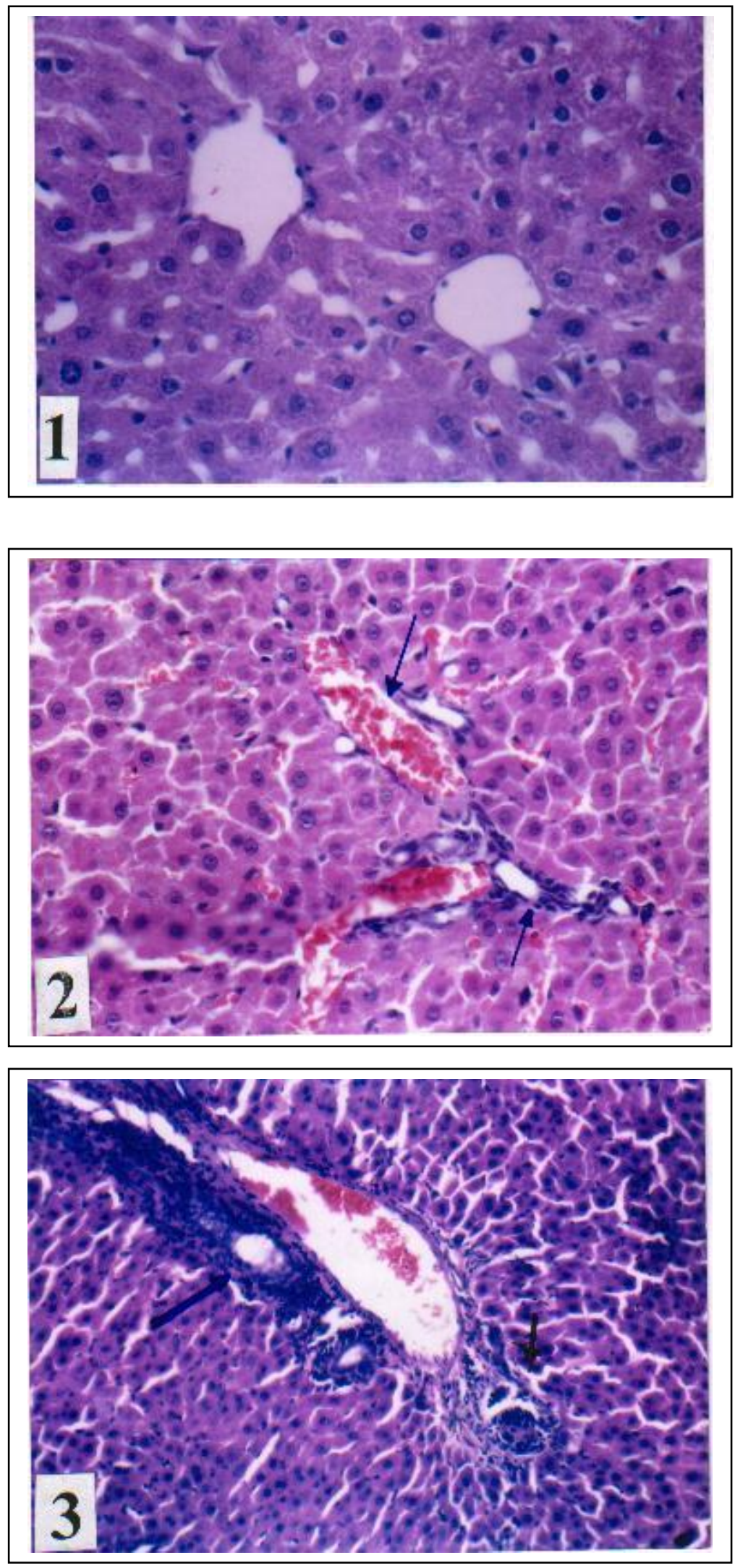

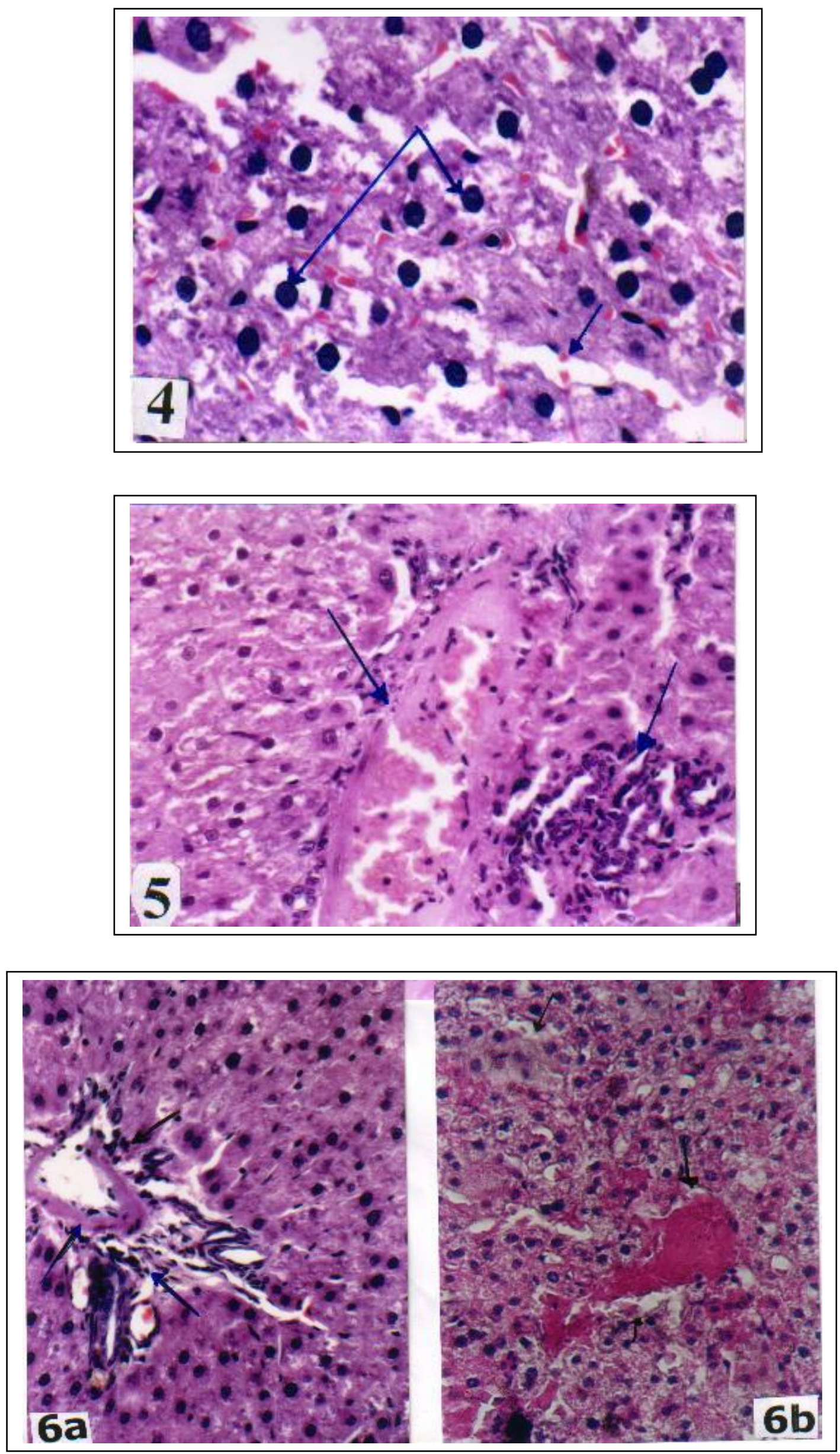

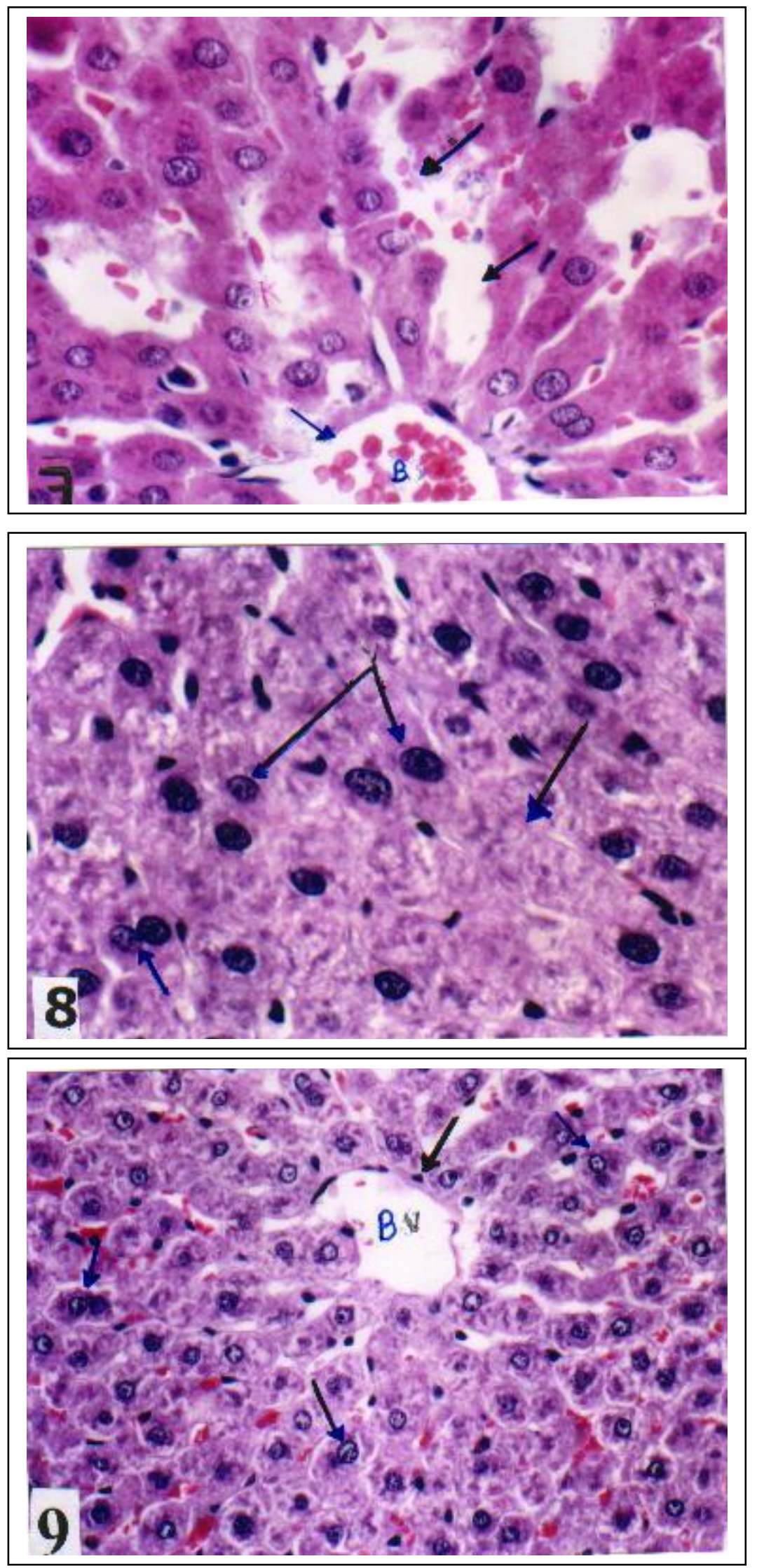

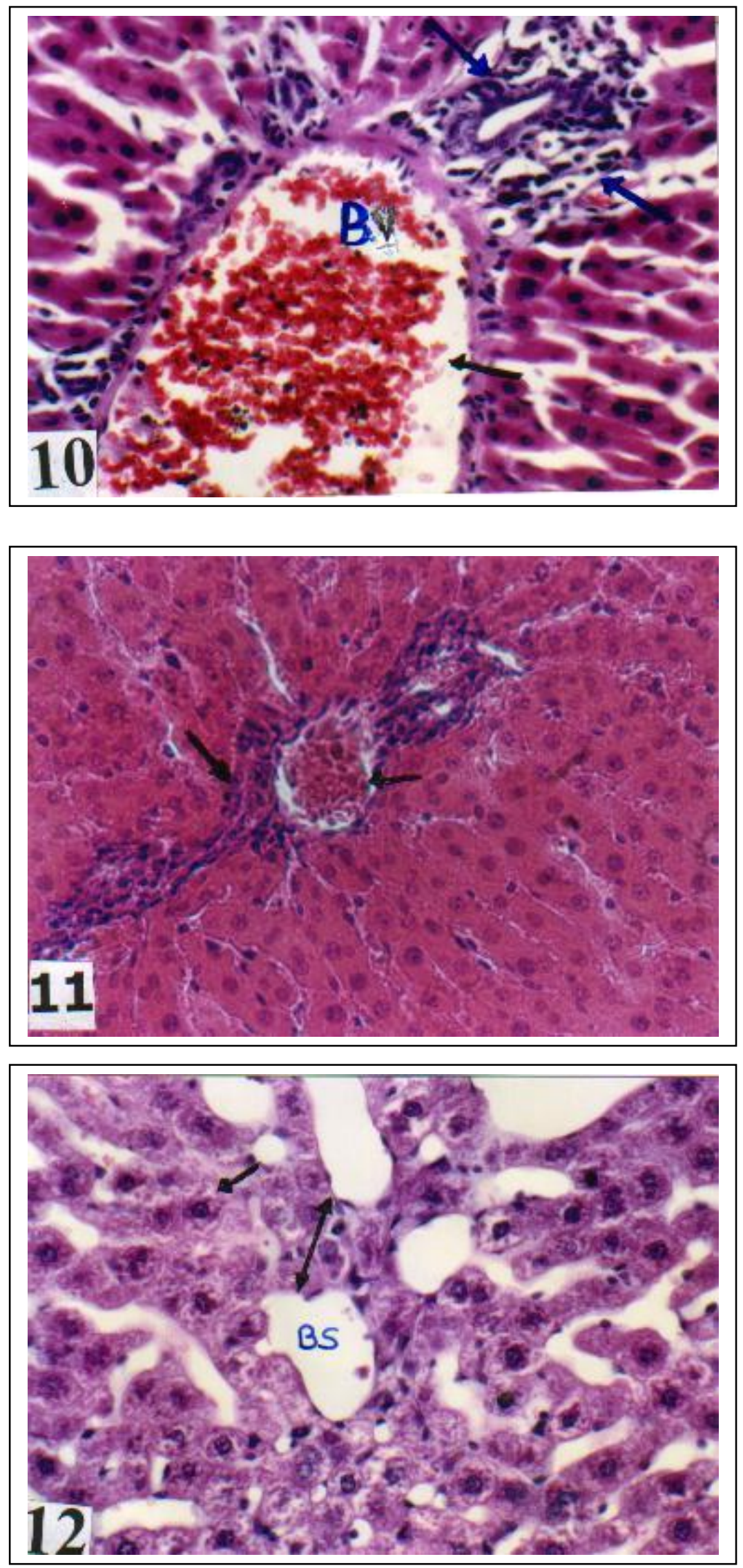
Modifying effects of Soybean and Nigella............
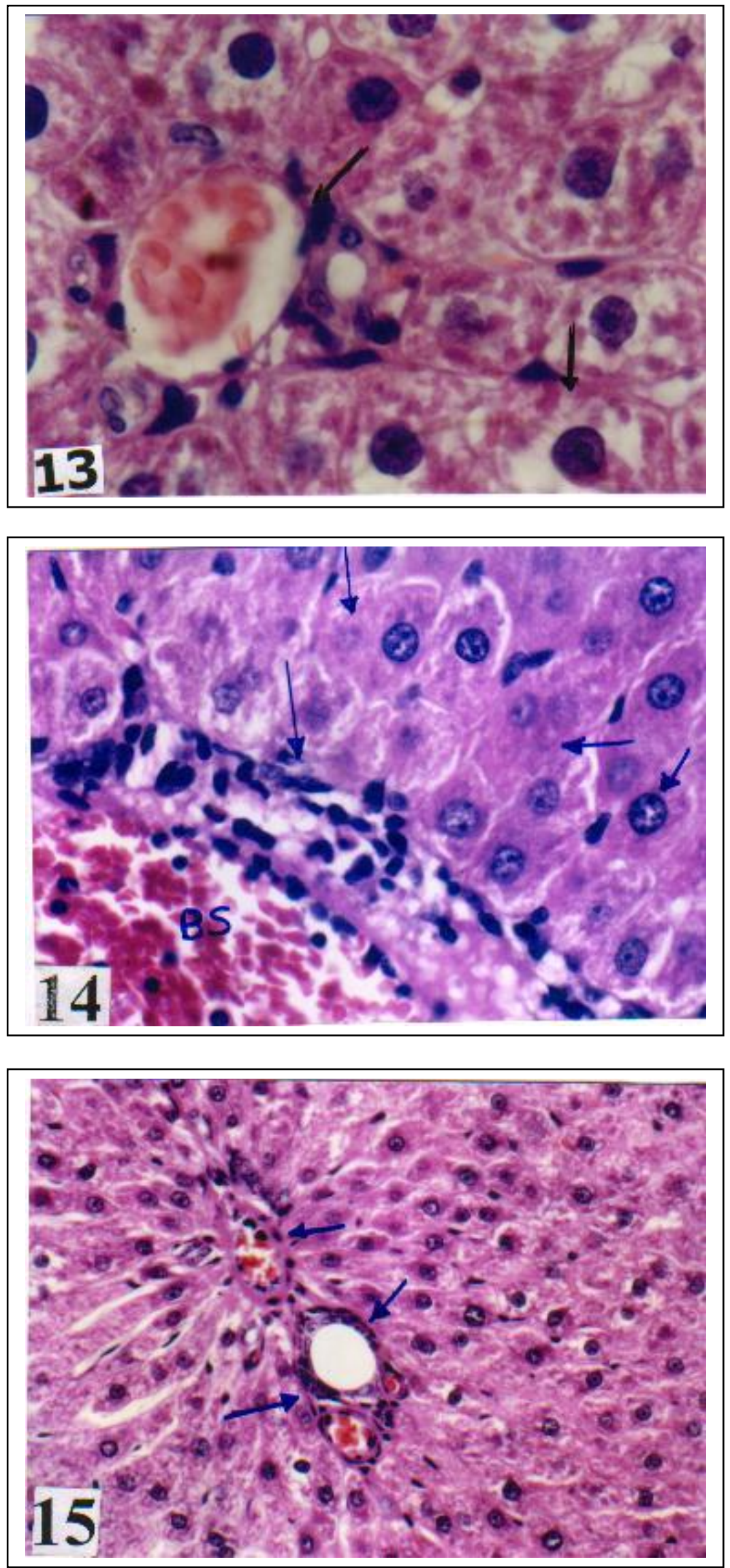
Hanaa F. Waer et al
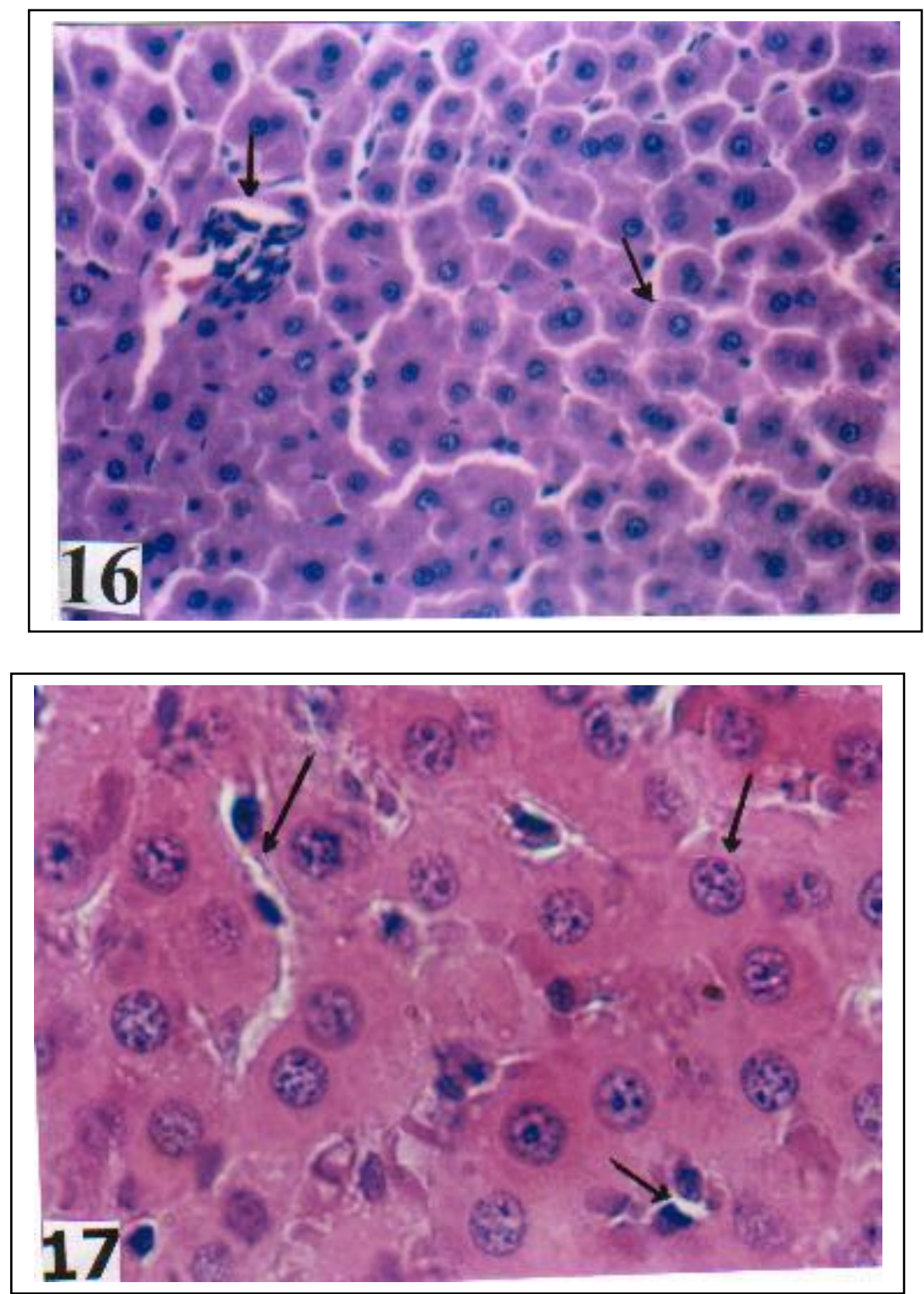

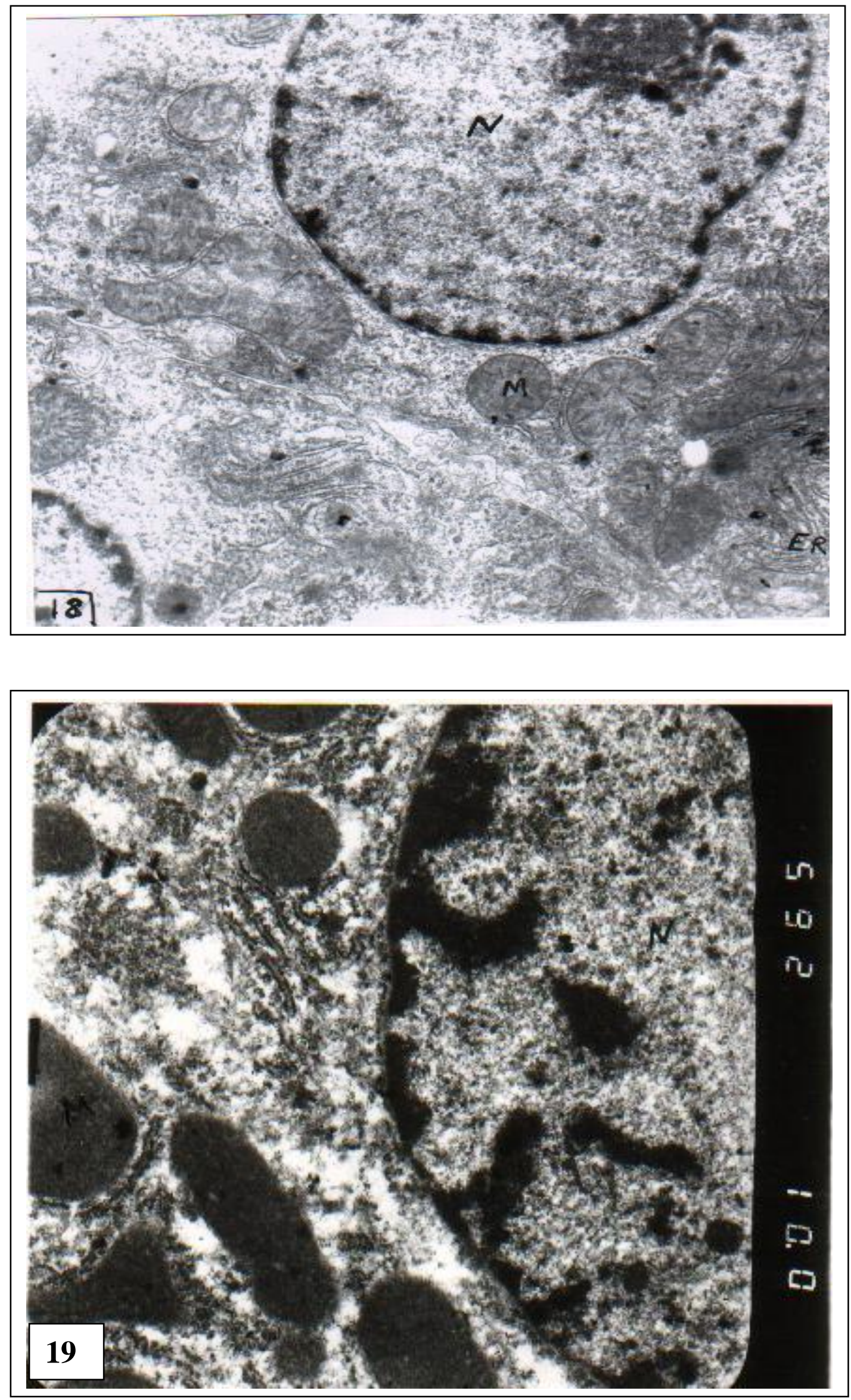

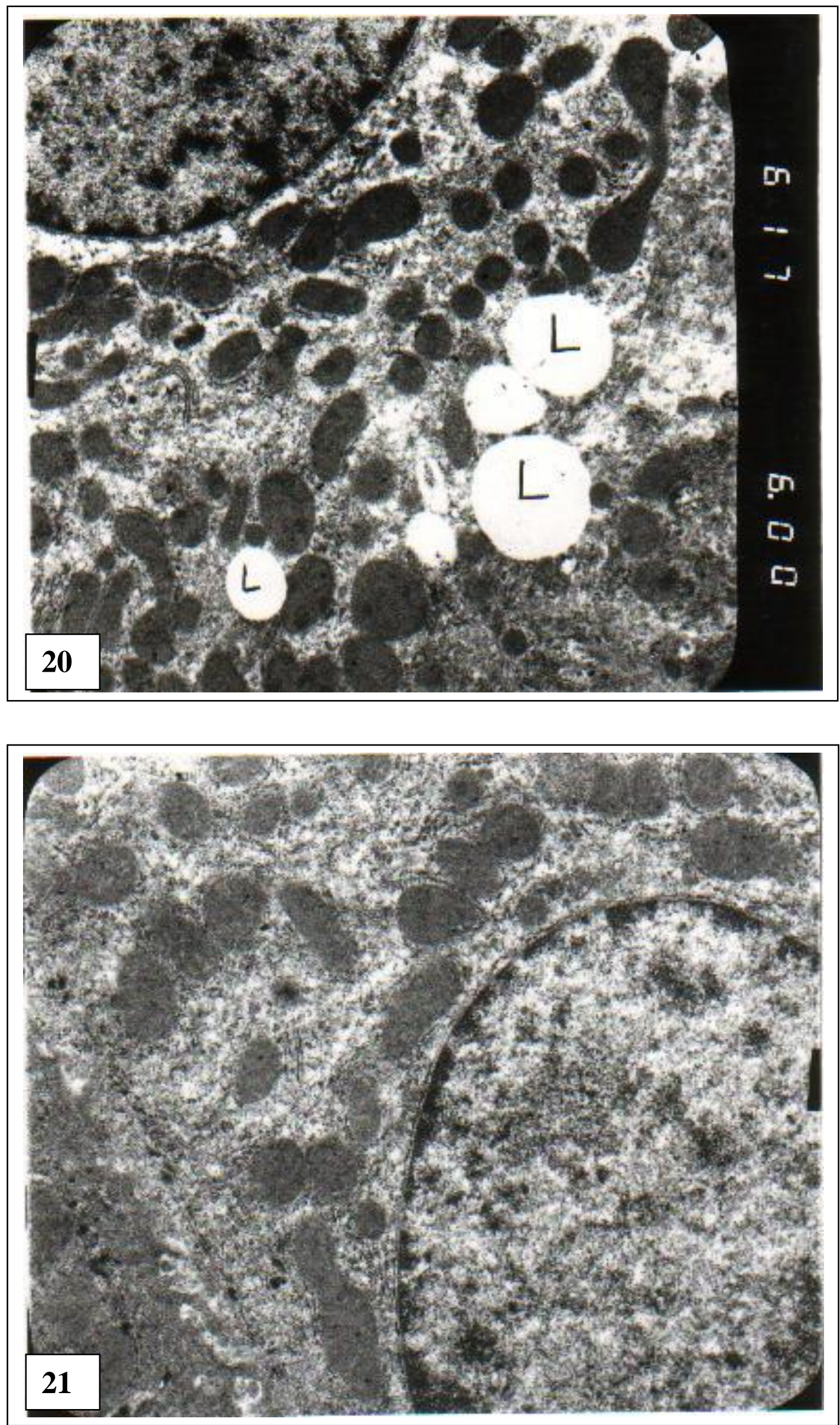

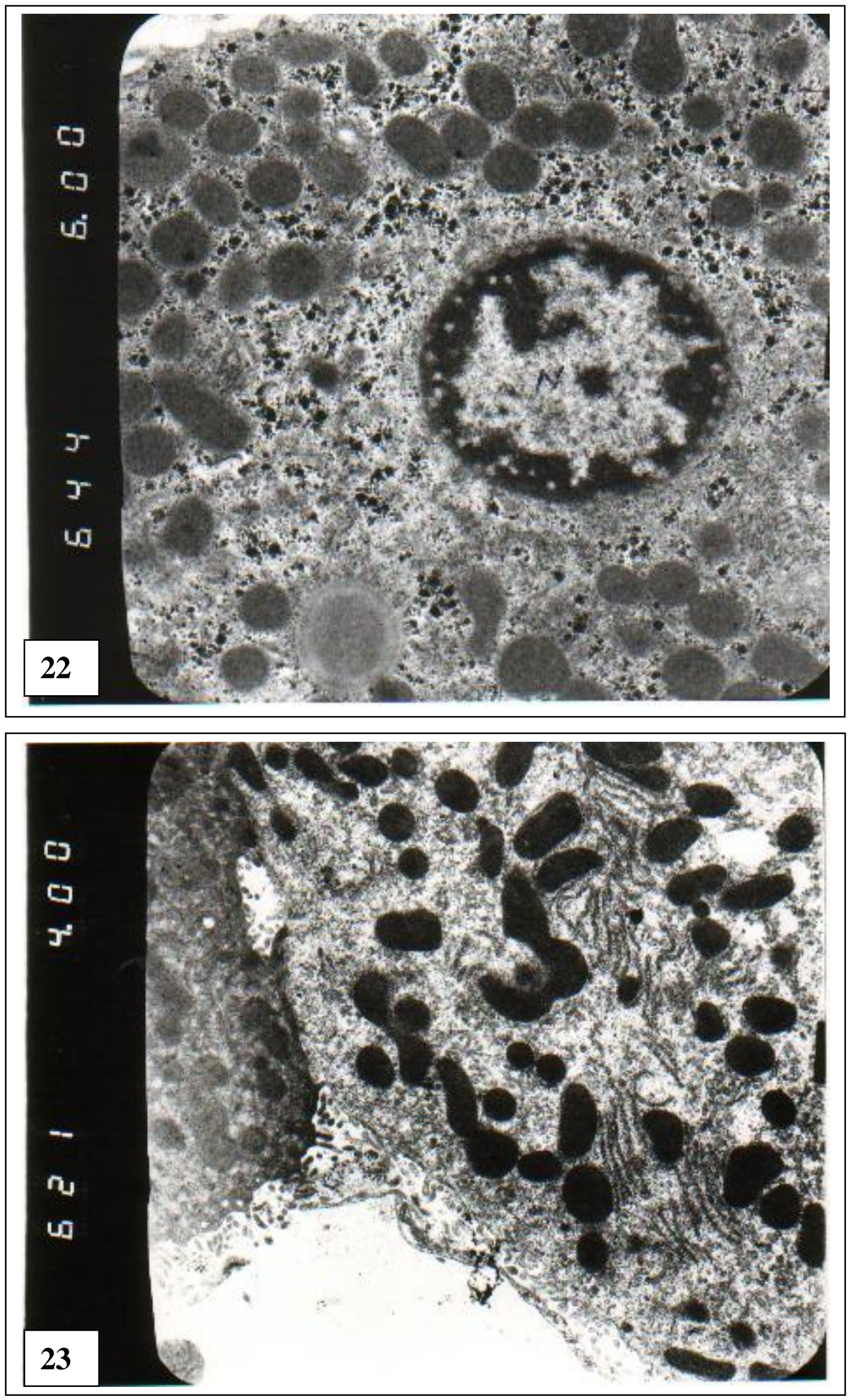

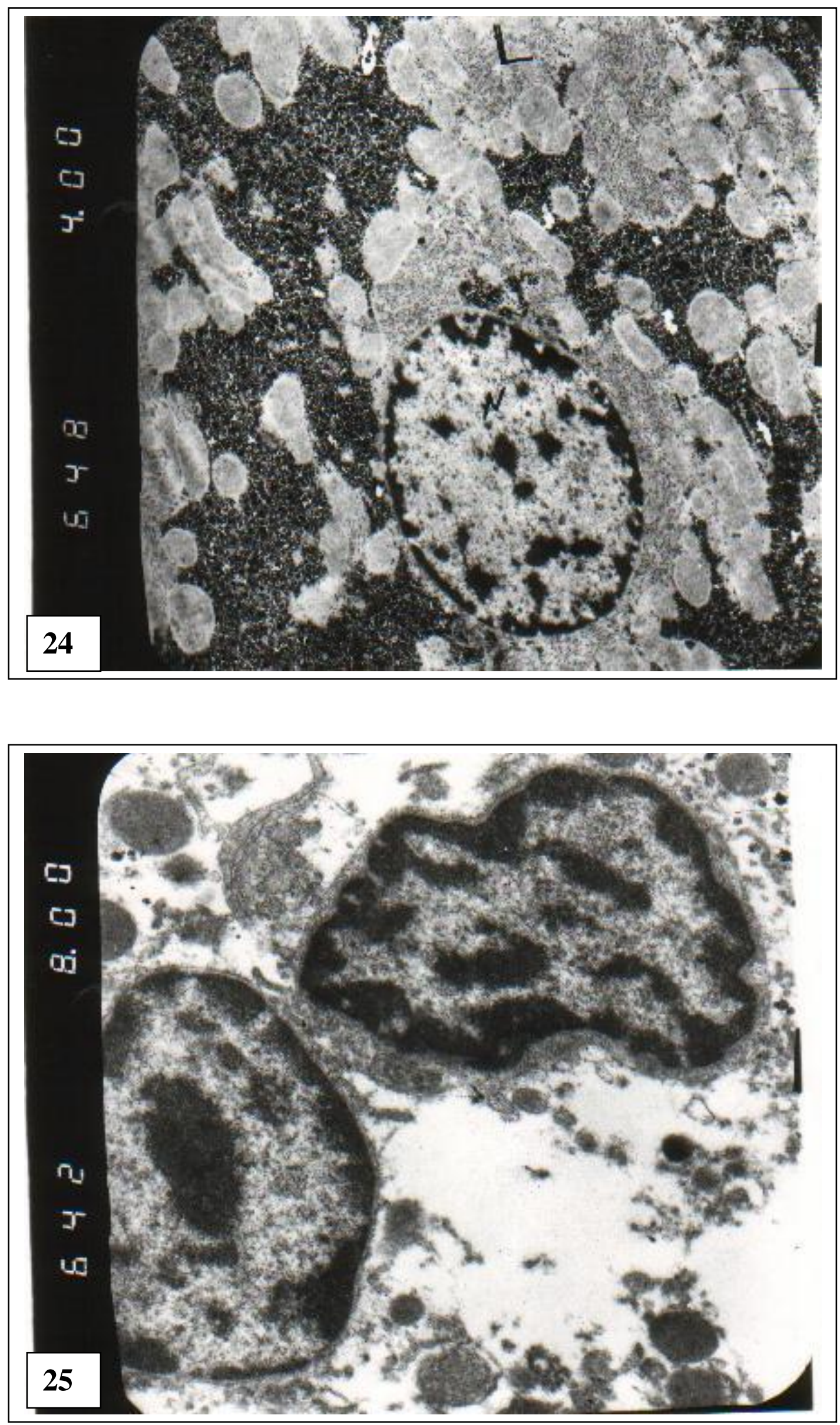

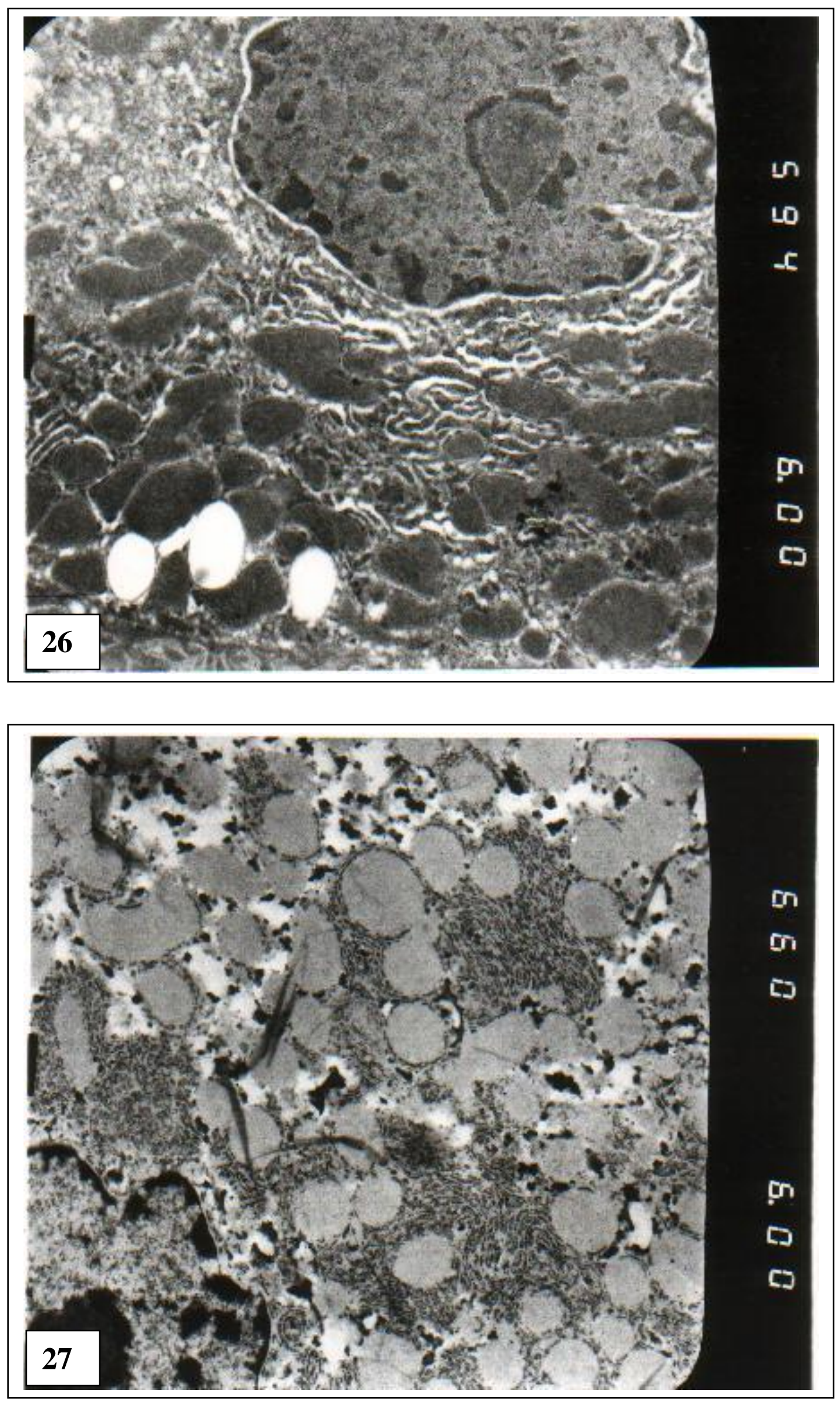

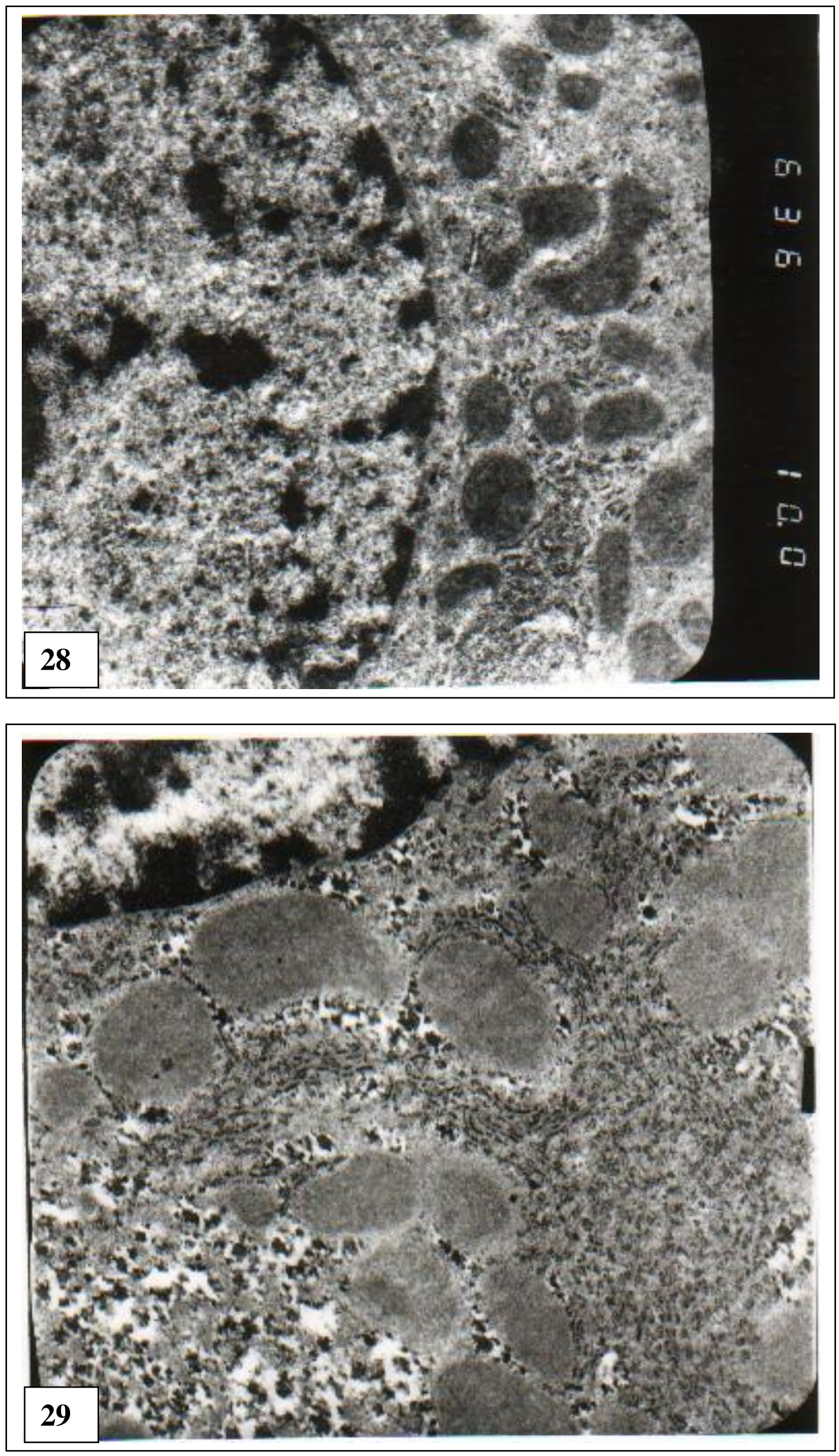


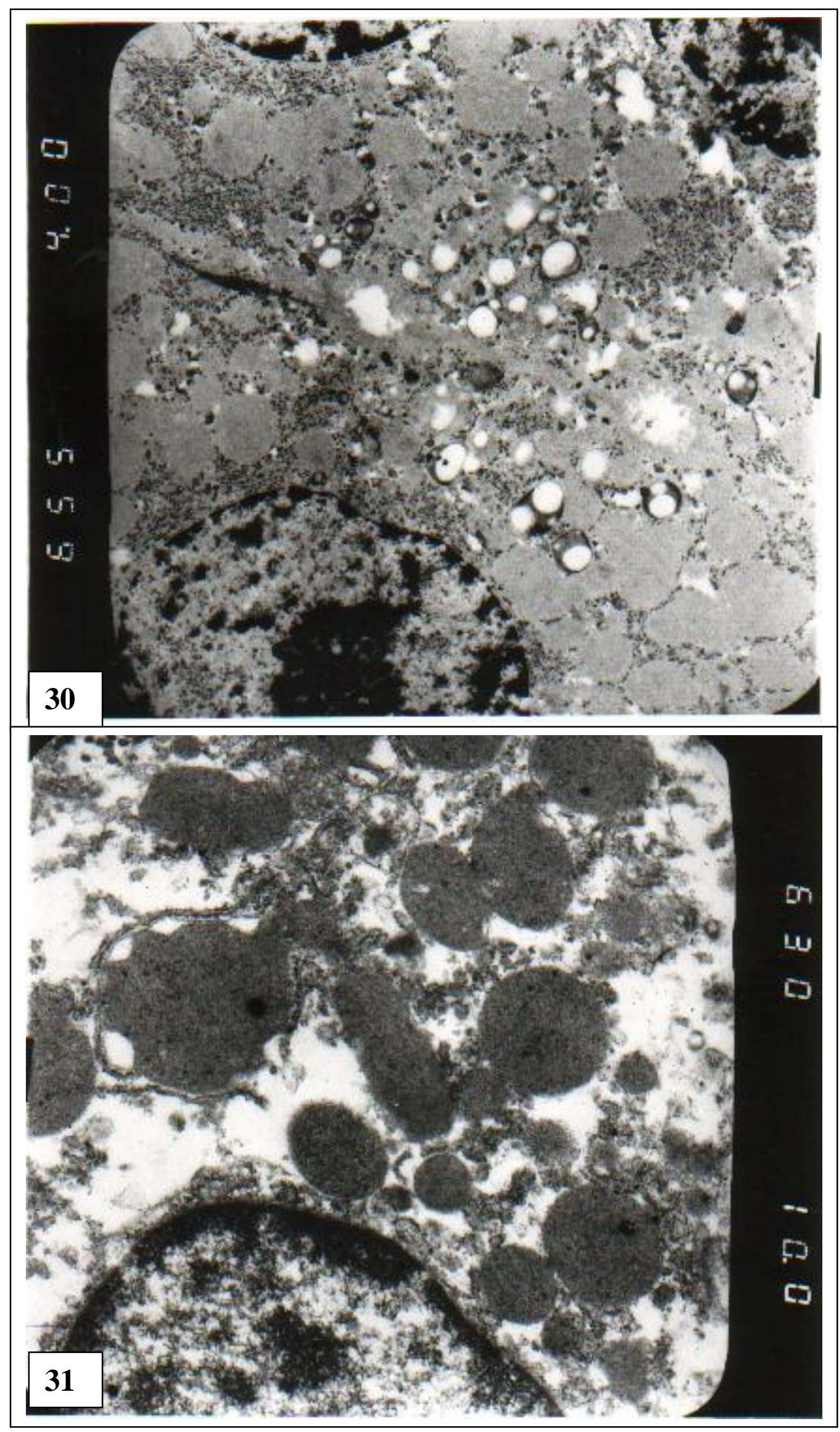



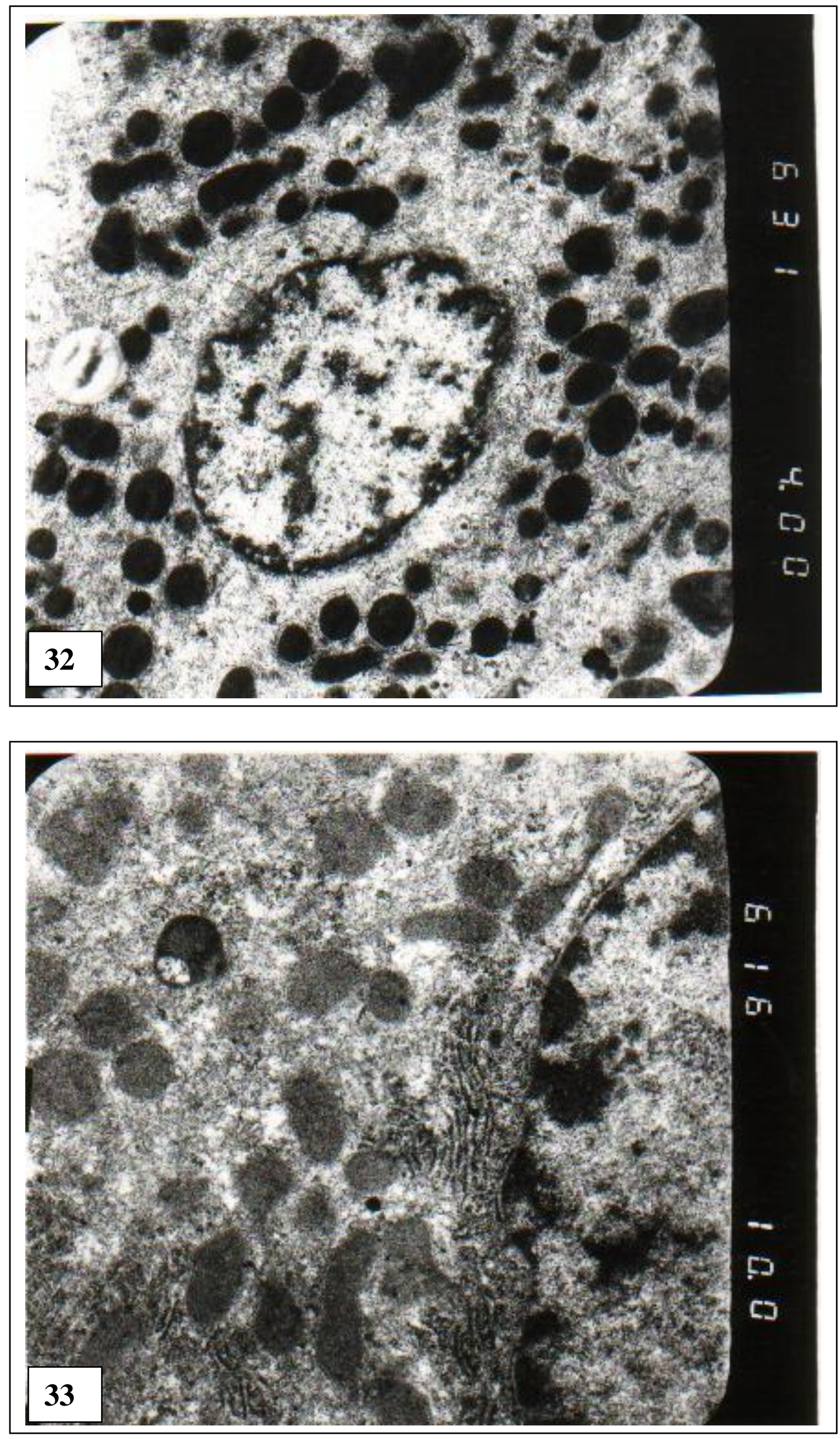
Modifying effects of Soybean and Nigella............
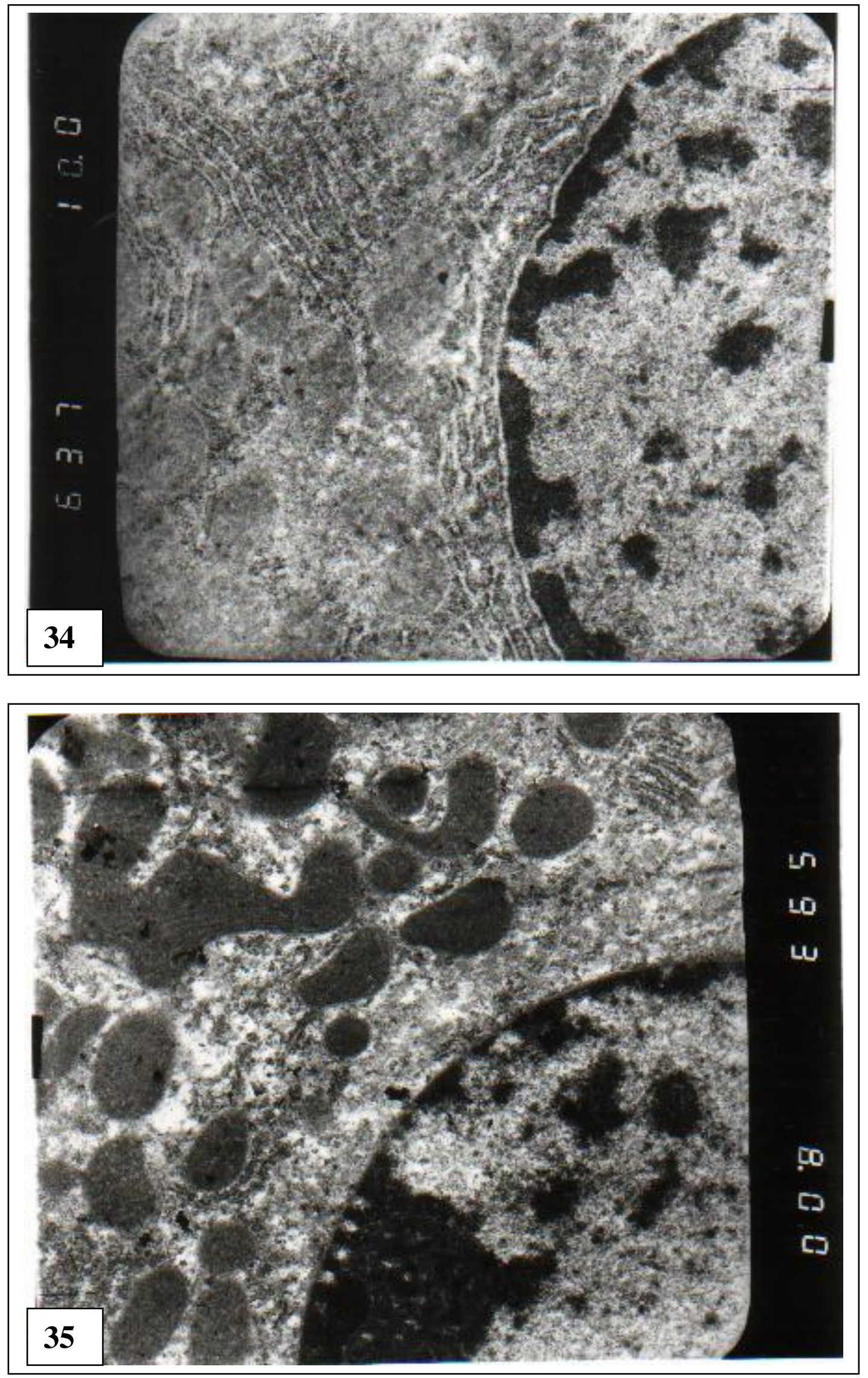

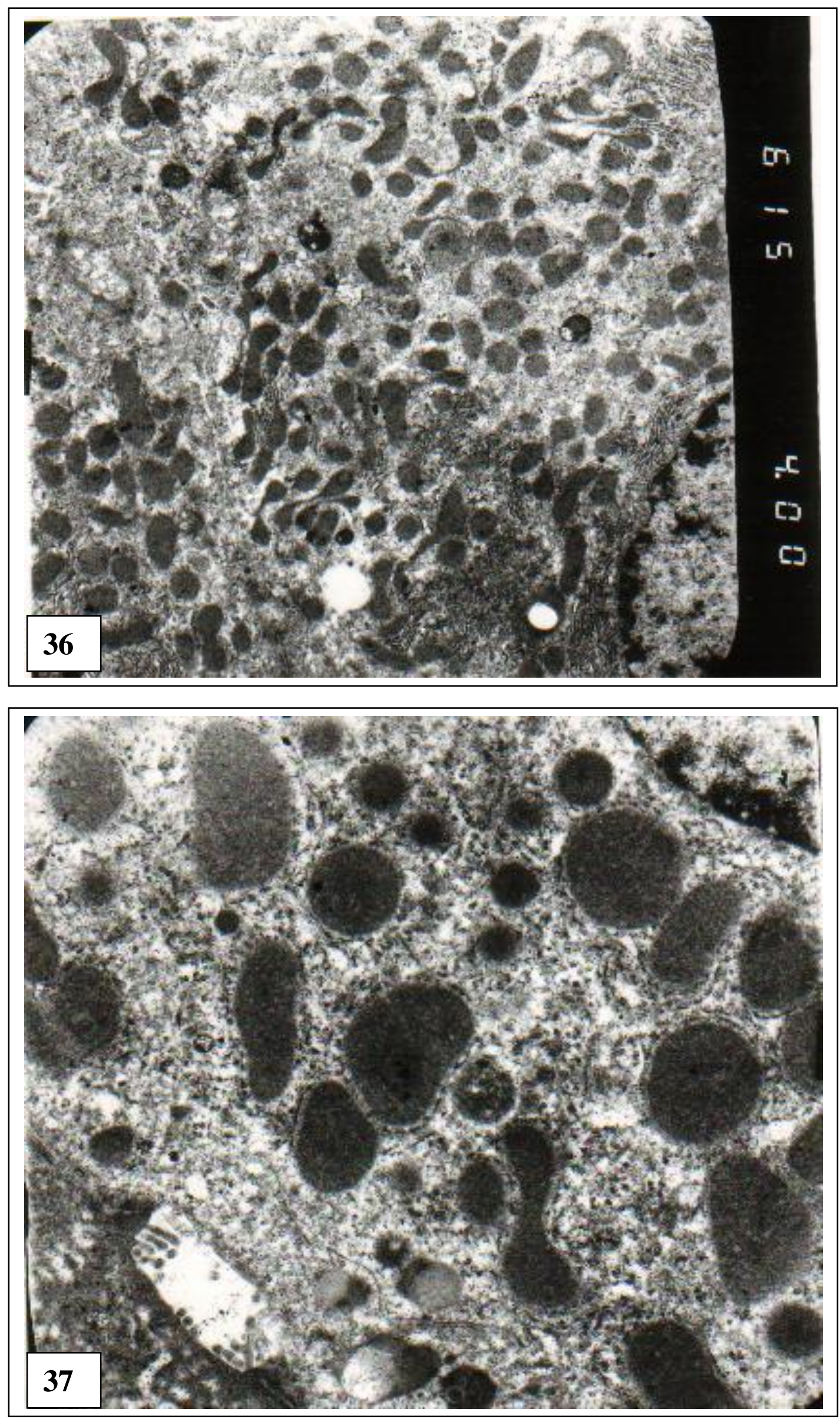


\section{Discussion:}

Hepatocellular carcinoma (HCC) is the most common primary malignancy in the liver on a world wide basis. It represents about $83 \%$ of all primary malignant hepatic tumors (Edmondson \& Craig, 1987). In Egypt, the incidence of HCC was $37 \%$ of the total number of malignant cases (Abdel Razek et al., 1989).

The present results showed that nitrosamine caused a sever changes in the structure of the cell of the liver. Preservation of hepatic lobular pattern which is a sign of cell death illustrated in densely stained Pycknotic nuclei and hyalinization and lyses of the cytoplasm are common.

Possible mechanisms of action of nitrosamines:

The induction of cancers by single doses of rapidly eliminated nitrosocarcinogens implies on interaction between the carcinogen and product of its decomposition with some components of the cells. Two mechanisms may be operating in tumor induction by the nitrosamines. The first mechanism, namely penetration of cellular macro-molecules in metabolic control, is based on the observations that all the nitrosamines tested show potent hydrogen bonding and protein penetration (Argus et al., 1965). Nitrous acid is very effective of nitrous acid from a nitroso compound inside the cell close to a critical receptor site might be carcinogenic. The second mechanism is alkylations of nucleic acid bases after its reaction with active diazoalkanes. Hydrazones derivatives are possible intermediates in nitrosamine carcinogenesis since hydrozoans is carcinogenic in the mouse. Hydrazones and some of its derivative are mutagenic. Although Health and Dutton (1958) could not detect any of its nitrous acid and derivatives of hydroxylamine and hydrozoan in rat treated with dimethyl nitrosamine the possibility exists that trace amounts might have been formed which reacted with available chemical grouping in the cells (Wei et al., 2000).

A cancer protective effect from plantderived foods has been found with uncommon consistency in epidemiologic studies. However, it has been difficult to identify specific components responsible for this effect. Many phytochemicals have been shown to be biologically active and they may interact to protect against cancer (La Marchand 2002).

Aoki, et al., (2002) suggested that intake of soy protein itself, but not soy isoflavones and saponins, reduces parquetinduced oxidative stress in rats, although this effect was not due to reduced absorption of parquet from digestive organs.

In recent years, experimental studies have provided growing evidence for the beneficial action of flavonoid on multiple cancer-related biological pathways (carcinogen bioactivation, cell-signaling, cell cycle regulation, angiogenesis, oxidative stress, inflammation). Although the epidemiologic data on flavonoid and cancer are still limited and conflicting, some protective associations have been suggested for flavonoid-rich foods (soy and premenopausal breast cancer; green tea and stomach cancer; onion and lung cancer).

On the other hand Kanter et al., (2004) suggested that NS treatment exerts a therapeutic protective effect in diabetes by decreasing oxidative stress and preserving pancreatic beta-cell integrity. Consequently, NS may be clinically useful for protecting beta-cells against oxidative stress. Khan $e t$ al., (2003) found that Nigella sativa is a potent chemo preventive agent and may suppress $\mathrm{KBrO} 3$-mediated renal oxidative stress, toxicity and tumor promotion response in rats.

The results obtained from Mabrouk et al., (2002) showed that supplementation of diet with honey and Nigella sativa has a protective effect $\mathrm{MNU}$-induced oxidative stress, inflammatory response and carcinogenesis.

This work focuses on the biological effects of the soy bean and Nigella Sativa, as well as the epidemiologic evidence that support their potential cancer protective properties.

A decoction comprised of Nigella 
sativa seeds, and soy bean is used to treat cancer. However, the anti-carcinogenic properties of this decoction have not been experimentally confirmed. The purpose of this study was to determine whether the above decoction could protect against chemically induce hepato-carcinogenesis. Rats gives DBA $+\mathrm{NaNO}_{3}$ and fed with soy bean and/or Nigella sativa for $3-12$ months help very much the liver cells to retain their normality with remarkable regeneration restricted in mitotic figures and activation of the nucleus. The blood sinusoids and the bile duct become normal with normal cell linings, binucleated cells as a regression of the effect of nitrosodiethylamine. Under the electron microscopically level marked signs of recovery illustrated in that the nucleus is well defined with double membrane pores and normal chromatin. These findings agree with Arliss \& Biermann, (2002). Akaza et al., (2002), stated that soy bean isoflavones act as inhibitory factor in liver cancer

Wu et al., (2002) declared that high soy intake in childhood in Asian-Americans is associated with reduced breast cancer risk. Risk may further reduced by intake as an adult.

The mechanism by which Nigella sativa seeds, and soy bean mediates their anti-carcinogenic effects is not clear. Antitumor effect of the decoction may be mediated according to Enomoto et al., (2001) by one or more of the following mechanisms:

(a) Detoxification of the carcinogen by inducing detoxification enzymes such as GSTs. (b) Anti-oxidant activity., (c) Immune modulator action. (d) Cytotoxicity. Finally it can be declared that soybean in combination with Nigella sativa give a good protective effect.

The overall results obtained in the present study indicate that $N$. Sativa and soy bean have the potential to inhibit the early initiated phase of hepatocarcinogenisis.

\section{References:}

1. Abdel-Razek, S.M.; ElTabbakh, H.A. and Francies, M.R. (1989) : Delection of hepatitis B-virus persistence and carcinogenesis, histopathological study. Egypt. J. Lab. Med., 1: 129-132.

2. Akoza, H.; Miyanaga, N.; Takashima, N.; Naito, S.; Hirao, Y.; Tsukamoto, T. and Mori, M. (2002) : Is daidzen non-metabolizer a high risk for prostate cancer? A case controlled study of serum soybean isoflavone concentration. Jpn. J. Clin. Oncol., 32(8): 296300

3. Aoki H, Otaka Y, Igarashi K, Takenaka A. 2002Soy protein reduces paraquat-induced oxidative stress in rats.J. Nutr. Aug;132(8):2258-62

4. Argus, M.F.; Arcos, J.C. and Hoch-Ligeti, C. (1965) : Studies on the carcinogenic activity of protein denaturing agents. Hepatocarcino-genicity of dioxins. J. Nat. Cancer Inst., 35: 949-952.

5. Arliss, R.M. and Biermann, C.A. (2002) : Do soy isoflavones loer cholesterol, inhibit atherosclerosis, and play a role in cancer prevention? Holist Nurs Pract., 15(5): 40-48.

6. Benghuzzi et al., (2003), Benghuzzi JT Hansen, H, Tucci M, Cason Z. (2003) : The role of black seed in the proliferation and biochemical marker levels of Hep-2 cells. Biomed Sci Instrum.;39:371-6

7. Carleton, H.M. (1980) : "Histological Technique". $6^{\text {th }}$ Ed., Oxford University Press, New York, Toronto

8. Druckrey, H.; Preussmann, R.; Ivankovtc, B. and Schmähl, S. (1969): Organotrope carcinogen wirkungen bei verschiede nen Nitrosoeverbindungen an Boratten. Z. Krebsforsch, 69: 103107.

9. Edmondson, H.A. and Craig, J.R. (1987) :Peripheral cholangio-carcinoma, neoplasmma of liver. In: Disease of the liver. Edited by Schiff, L. and Schiff, E., ed. 6, J.B. Lippincott, Philadelphia. 
10. Enomoto, S.; Asamo, R.; Iwahori, Y.; Narui, T.; Okada, Y.; Singab, A.N. and Okuyama, T. (2001) : Hematological studies on black cumin oil from the seeds of Nigella sativa L. Biol. Pharm. Bull. Mar., 24(3): 307-310

11. Health and Dutton, A. (1958) : the detection of metabolic products from dimethylnitrosamine in rats and mice. Biochem. J. 70: 619-621

12. Iddamaldeniya SS, Wickramasinghe $\mathbf{N}$, Thabrew I, Ratnatunge N, Thammitiyagodage MG (2003 ):Protection against diethylnitrosoamineinduced hepatocarci-nogenesis by an indigenous medicine comprised of Nigella sativa, Hemidesmus indicus and Smilax glabra: a preliminary study. J Carcinog. Oct 18;2(1): 6.

13. Lijinsky, W. \& Epstein, S. S. (1970) Nitrosamines as Environmental Carcinogens, Nature, 225, 21-23

14. Islam SN, Begum P, Ahsan T, Huque S, Ahsan M. (2004) :Immunosuppressive and cytotoxic properties of Nigella sativa. Phytother Res. May;18(5):395-8

15. Khan N, Sharma S, Sultana S (2003 :)Nigella sativa (black cumin) ameliorates potassium bromate-induced early events of carcinogenesis: diminution of oxidative stress. Hum Exp Toxicol. Apr;22(4):193-203.

16. Kanter M, Coskun O, Korkmaz A, Oter S. (2004):Effects of Nigella sativa on oxidative stress and beta-cell damage in streptozotocin-induced diabetic rats. Anat Rec. Jul; 279A (1): 685-91

17. Lee, C.C.; Liu, J.Y.; Lin, J.K.; Chu, J.S. and Shew, J.Y. (1998) : $\mathrm{P}^{53}$ point mutation enhanced by hepatic regeneration in aflatoxin B1-induced rat liver tumors and preneoplastic lesions. Cancer Lett. Mar. 13; 125(1-2): 1-7

18. Lee, Y.Y.; Kim, H.G.; Jung, H.I.; Shin, Y.H.; Hong, S.M.; Park, E.H.; Sa, T.H. and Lim, C.J. (2002) : Activities of antioxidant and redox enzymes in human normal hepatic and hepatoma cell lines. Mol. Cells. Oct. 31; 14(2): 305-311.

19. Le Marchand L. (2002:) Cancer preventive effects of flavonoids-a review. Biomed Pharmacother. Aug;56(6):296-301.

20. Liu HQ, Ren CY, Jia LS, Yao XX, Ren XL1996. Effects of acute hepatic dam age on natriuresis and water excretion after acute normal saline loading in rats .Shijie Huaren Xiaohua Zazhi,;4:176-178

21. Mabrouk GM, Moselhy SS, Zohny SF, Ali EM, Helal TE, Amin AA, Khalifa AA 2002 Sep Inhibition of methyl-itrosourea (MNU) induced oxidative stress and carcinogenesis by orally administered bee honey and Nigella grains in Sprague Dawely rats. J Exp Clin Cancer Res.;21(3):341-6

22. Magee, P.N. and Barnes, J.M. (1967) : Carcinogenic nitroso compounds, from: Advances in cancer research edited by Haddow, a. and Weinhouse, S., Vol. 10: 163, Academic Press, New York, London.

23. Moss, D.W. and Henderson, A.R. (1996) : Enzymes. In: Tietz Fundamentals of Clinical Chemistry, $4^{\text {th }}$ ed., Burits, C.A.; Ashwood, E.R., Eds., Philadelphia, WB. Saunders Company, pp. 283-335.

24. Sakata K, Hara A, Hirose Y, Yamada Y, Kuno T, Katayama M, Yoshida $\mathbf{K}$, Zheng $\mathbf{Q}$, Murakami A, Ohigashi H, Ikemoto $\mathbf{K}$, Koshimizu $\mathbf{K}$, Tanaka T, Mori H. (2004) :Dietary supplementation of the citrus antioxidant auraptene inhibits N,N-diethylnitrosamineinduced rat hepatocarcinogenesis. Oncology. 66(3):244-52.

25. Salim EI, Fukushima S. . 2003 Chemopreventive potential of volatile oil from black cumin (Nigella sativa L.) seeds against rat colon carcinogenesis. Nutr Cancer;45(2):195-202 
26. Singh JP, Selvendiran K, Banu SM, Padmavathi R, Sakthisekaran D. (2004) :Protective role of Apigenin on the status of lipid peroxidation and antioxidant defense against hepatocarcinogenesis in Wistar albino rats. Phytomedicine.;11(4):309-14.

27. Taniguchi M, Yasutake A, Takedomi K. (2000) : Effects of dietary sulfur-containing amino acids on oxidative damage in rat liver caused by $\mathrm{N}$ nitrosodimethylamine administration. $\mathrm{Br} \quad \mathrm{J}$ Nutr. Aug;84(2):211-7

28. Terracini, B., Magee, P. N. \& Barnes, J. M. (1967) Hepatic Pathology in Rats on Low Dietary Levels of Dimethylnitrosamine, Brit. J.Cancer. 21, 559-565

29. Tohamy AA, el Ghor AA, Moharram NZ, el-Shazly MM. (.1996) : Protective role of soybean feeding against the cytogenetical and histopathological effects of dibutylamine and sodium nitrate on bone marrow and liver of mice. Mutat ResAug 8;360(3):155-63.

30. Venable, J.H. and Coggeshall, R. (1965) : A simplified lead citrate stain for use in electron microscopy. J. cell Biol., 25: 407408.

31. Wei, M.; Wanibuchi, H.; Yamamoto, S.; Iwai, S.; Morimura, K.; Nomura, T.; Takayama, R. and Fukushima, S. (2000) : Chemo-preventive effects of s-methyl-cysteine on rat hepatocarcinogenesis induced by concurrent administration of sodium nitrite and morpholine. Cancer Lett. Dec., 8; 161(1): 97103.

32. Wu, X.S.; Serota, D.G.; Ware, J.H.; Crowell, J.A. and Kennedy, A.R. (2002) : Detection of Bowman-Brik inhibitor and anti-Bowman-Birk inhibitor antibodies in sera of humans and animals treated with Bowman-Birk inhibitor concentrate. Nutr. Cancer, 43(2): 167-173.

\section{التأثير المحسن لفول الصويا والحبة السوداء ضد سرطان الكبد المحدث بالنيتروز أمين في الفئران الفودان}

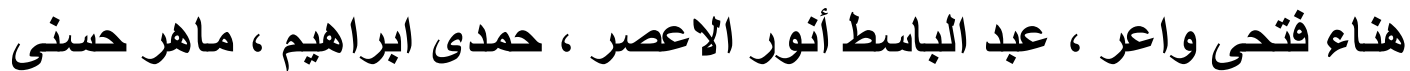

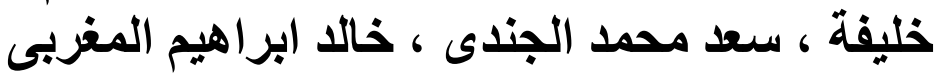

$$
\begin{aligned}
& \text { *المركز القومى لبحوث و تكنولوجيا الاشعاع / هيئة الطاقة الذرية ــ القاهرة ، **معهد }
\end{aligned}
$$

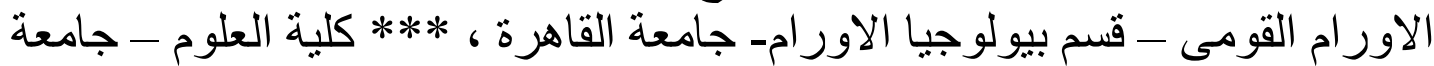

$$
\begin{aligned}
& \text { المنصورة - قسم علم الحيوان ، ****كلية العلوم - جامعة القاهرة - قسم علم الم }
\end{aligned}
$$

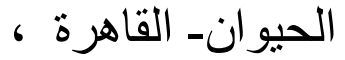

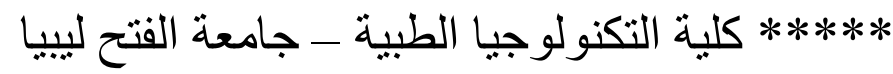

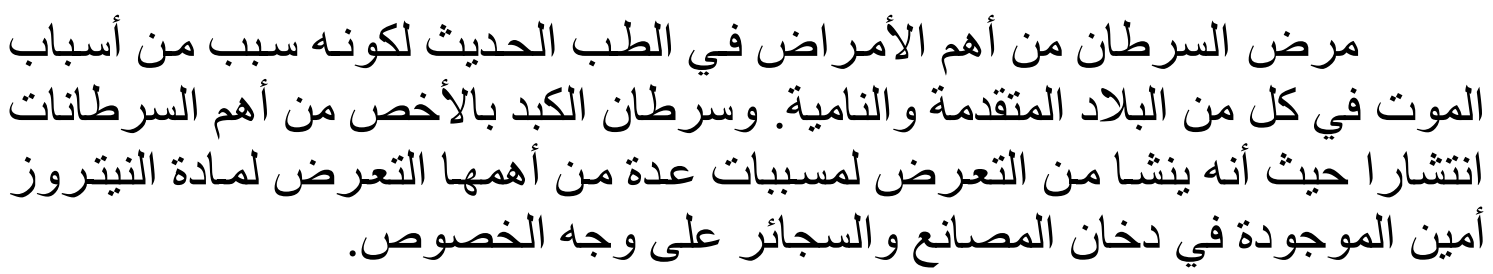




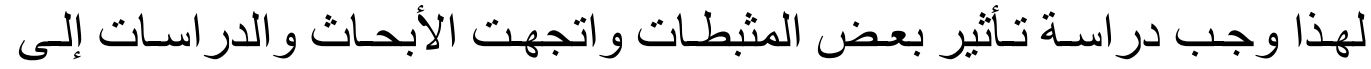

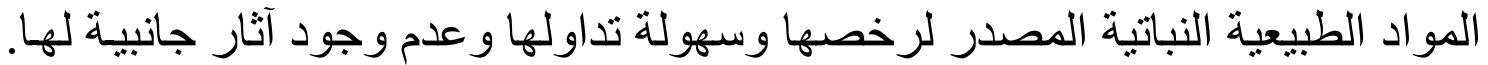

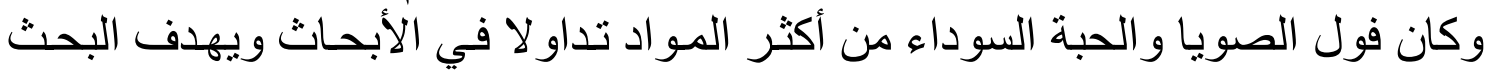

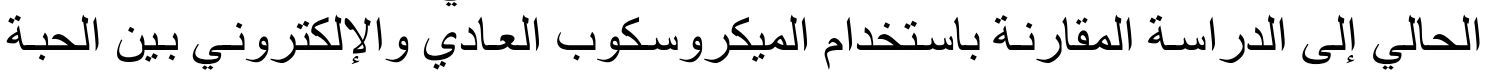

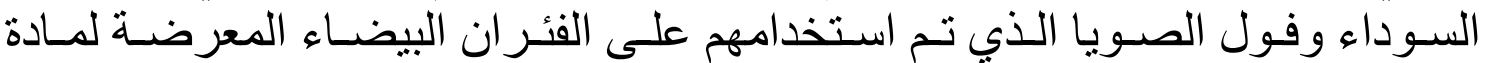
النيتروز أمين المحدثة لأور ام الكبد وكانت المعالجة على فتر المترات متساوية تتر اوح من 3

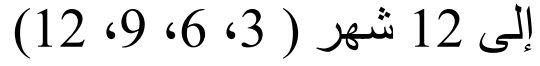

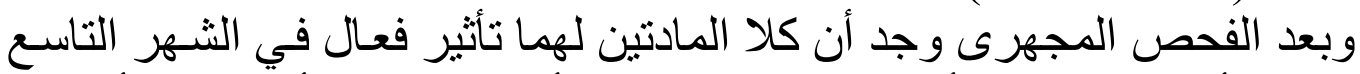

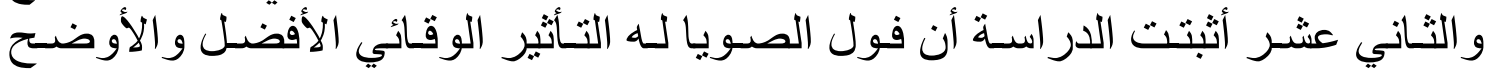
بالمقارنة لحبة البركة. 